\title{
Competition and the Cost of Debt*
}

\author{
Philip Valta ${ }^{\dagger}$ \\ HEC Paris
}

This version: February 14, 2012

\begin{abstract}
This paper empirically shows that the cost of bank debt is systematically higher for firms that operate in competitive product markets. Using various proxies for product market competition, and reductions of import tariff rates to capture exogenous changes to a firm's competitive environment, I find that competition has a significantly positive effect on the cost of bank debt. Moreover, the analysis reveals that the effect of competition is greater in industries in which small firms face financially strong rivals, in industries with intense strategic interactions between firms, and in illiquid industries. Overall, these findings suggest that banks price financial contracts by taking into account the risk that arises from product market competition.
\end{abstract}

JEL Classification: G18, G32

Keywords: Product Market Competition, Import tariffs, Cost of debt, Bank loans

* This paper is based on the first chapter of my dissertation at the Ecole Polytechnique Fédérale de Lausanne. I thank Erwan Morellec, my dissertation advisor, for invaluable guidance and constant support. I am grateful to Xin Chang, Rüdiger Fahlenbrach, Giovanni Favara, Simon Gervais, Aleksandar Georgiev, John Graham, Amit Goyal, Uli Hege, Filippo Ippolito, Alexandre Jeanneret, Rich Mathews, Boris Nikolov, David Oesch, Manju Puri, Jean-Charles Rochet, Enrique Schroth, René Stulz, S. Viswanathan, Alexei Zhdanov, and especially Laurent Frésard and Gordon Phillips (the referee) for helpful comments and suggestions. Moreover, I thank seminar participants at Copenhagen Business School, ESCP, ESSEC, HEC Paris, HKUST, LBS, NHH Bergen, Norwegian School of Management BI, UBS, University of Amsterdam, University of Lausanne, University of Notre Dame, University of Rochester, University of Zurich, VU Amsterdam, the 2010 EFA meetings, the 2010 AFFI meetings, and the 2009 Swiss Doctoral Workshop in Gerzensee for valuable comments. I also thank Michael Roberts for sharing the Compustat-Dealscan link file with me.

${ }^{\dagger}$ HEC Paris, 1 Rue de la Liberation, 78351 Jouy-en-Josas, France. Tel.: +33 1396797 42; Fax.: +33 139677085 ; E-mail: valta@hec.fr 


\section{Introduction}

Firms do not operate in isolation. They are in constant strategic interactions with other firms, struggling for customers and market shares. While some firms have the luxury of operating in less competitive product markets, others face severe competition. This intense competition fundamentally affects the firms' operating decisions and the riskiness of their business environment. While recent evidence supports the view that the intensity of competition has important implications for firms' cash flows and stock returns (Gaspar and Massa, 2006; Hou and Robinson, 2006; Irvine and Pontiff, 2009; Hoberg and Phillips, 2010a; Peress, 2010), the effect of competition on the pricing of debt has so far remained unclear. This lack of evidence is surprising. Debt is the dominant source of external finance and is crucial for firms' operating flexibility and for the financing of real investment activities. As such, it is important to understand whether and how the intensity of product market competition affects the pricing of debt. This paper aims to fill this gap and empirically investigates the relation between product market competition and spreads of bank loans.

There are a number of potential reasons why the price at which banks lend to firms depends on the competitive landscape. One reason relates to a firm's default risk. Firms with a higher default risk tend to pay higher rates for their loans. Since competition reduces pledgeable income and increases cash flow risk, competition could also increase firms' default risk. Moreover, firms constantly face a competitive threat from their rivals. For instance, financially strong firms could adopt aggressive competitive strategies that can significantly increase the business risk of incumbent firms (Bolton and Scharfstein, 1990). Alternatively, if firms cannot fully exploit their investment opportunities, they risk losing these opportunities and market share to rivals. In sum, the intensity of competition could increase the likelihood that firms default on their interest payments.

Another reason relates to a firm's asset liquidation value. When contracts are incomplete and transaction costs exist, liquidation values are of central importance for the pricing of debt contracts, because they provide creditors the right to possess assets when firms default on promised payments (Aghion and Bolton, 1992; Hart and Moore, 1994; Bolton and Scharfstein, 1996). As such, higher 
liquidation values allow firms to obtain lower rates for their loans (e.g., Benmelech, Garmaise, and Moskowitz, 2005). Since the competitive nature of the product market could affect the number and the financial strength of potential buyers and hence the asset liquidity of an industry (Ortiz-Molina and Phillips, 2011), competition could also affect the cost of bank debt by changing the firm's liquidation value.

Using a large sample of loan contracts from publicly traded U.S. firms over the years 1992 to 2007, I find strong empirical evidence that banks charge significantly higher loan spreads for loans to firms in competitive environments. Using the Herfindahl-Hirschman Index as a proxy for competition in three-digit Standard Industry Classification (SIC) code industries, loans in competitive industries have, on average, a spread which is $9.6 \%$ (17 basis points) higher than comparable loans in less competitive industries, controlling for other factors that affect spreads. In the sample, this difference translates into an average additional cost of debt of USD 527,000 per year. This result is robust to alternative industry classifications and empirical specifications. Specifically, I demonstrate that the result is robust to using the variable industry classification suggested by Hoberg and Phillips (2011). The result also holds when I control for a firm's credit rating, alternative proxies of default risk, lender fixed effects, firms' market share, stock returns, and anti-takeover provisions. Across all of these specifications, I uncover a substantial positive relation between the intensity of competition and loan spreads. These findings corroborate the main result and cast doubt on potential alternative explanations. Moreover, the results suggest that competition captures risk arising from the firm's competitive environment that goes above and beyond the risk captured by traditional proxies of default risk.

Next, in order to mitigate endogeneity concerns that financing choices impact industry structure, I follow Frésard (2010) and measure changes in the intensity of competition using exogenous reductions of industry-level import tariff rates. The idea is that unexpected reductions of trade barriers facilitate the penetration of foreign rivals into local markets and trigger an intensification of firms' competitive environment (Bernard, Jensen, and Schott, 2006). Using tariff data for the U.S. manufacturing sector, I identify 54 industries that experience a large import tariff rate reduction between 1992 and 2005. While 
average tariff rates decrease from $3 \%$ to below $1.5 \%$ in these industries, import penetration significantly increases from $19.5 \%$ to $24.1 \%$. As such, these tariff rate reductions facilitate the entrance of foreign rivals and increase the intensity of competition for domestic firms. Using these tariff rate reductions as a proxy for a sudden increase in the competitive pressure that firms face (competitive shock), the estimations reveal that these reductions in import tariff rates cause an increase in spreads by $15 \%$ to $22 \%$. Moreover, I find that the effect of a competitive shock is significantly larger for firms operating in concentrated industries and for firms not protected by other barriers to entry. These ancillary results further support the main finding and the use of this quasi-natural experiment setting.

In a next step, I use the cross-sectional dimension of the sample to examine how the effect of competition differs across industries and to further understand the nature and potential drivers of the effect. In particular, I explore how the difference between a firm and its rivals' financial status and the intensity of interactions within industries change the effect of competition on spreads. Consistent with the idea that the exposure to “competitive risk” depends on the difference between a firm and rivals' financial strength, I observe that the relation between competition and spreads is magnified when small firms face financially strong rivals. This result is consistent with a potential within-industry effect of competition as in Bolton and Scharfstein (1990). Moreover, the effect of competition on spreads is higher when the amount of strategic interactions within industries is high. I also investigate the extent to which the effect of competition depends on an industry's specificity and illiquidity of assets. The evidence points to noticeable differential effects. Specifically, the effect of competition on spreads is significantly larger in illiquid industries. As such, this result supports and complements recent findings that asset liquidity is an important determinant of firms’ cost of capital (Ortiz-Molina and Phillips, 2011). Overall, consistent with the idea that banks price "competitive risk", the impact of competition on spreads is significant and multifaceted.

This paper makes two main contributions to the literature. First, the paper provides evidence to support the view that product and financial markets have important linkages. While previous papers study, among others, the relation between industry structure and the quantity of debt (MacKay and 
Phillips, 2005; Xu, 2011), cash holdings (Morellec and Nikolov, 2008), or the cost of equity (Hou and Robinson, 2006; Hoberg and Phillips, 2010a), this paper focuses on the pricing of debt. Taken as a whole, the effect of competition on debt pricing appears to be substantial and to depend on both rivals' financial strength and industry structure. In particular, the results suggest that firms which hold a leading position in industries not only have access to cheaper financing, but could also increase the cost of financing for their rivals. As such, these findings point to potential externalities and spill-over effects between industry rivals. In this spirit, it relates to recent work by Leary and Roberts (2010), who show how firms’ capital structure decisions depend on the capital structure choices of their industry peers.

Second, this study contributes to the literature analyzing loan contracts. Recent empirical research devotes much effort to studying the determinants of loan contracts along pricing and non-pricing dimensions. ${ }^{1}$ Although these studies shed light on determinants of financial contracts, this paper points to an important new dimension. Specifically, it provides evidence that industry structure and the intensity of competition in the product market affect the pricing and, potentially, the design of financial contracts. The findings suggest that the competitive environment of firms needs to be taken into account when assessing a firm's cost of debt financing.

The remainder of the paper proceeds as follows. The next section develops the main hypotheses. Section 3 describes the data and the sample. Section 4 presents the results from panel estimations. Section 5 addresses the potential endogeneity of product market competition. Section 6 characterizes crosssectional differences. Finally, Section 7 concludes.

\footnotetext{
${ }^{1}$ These papers, among others, investigate how loan contracts are affected by firm and risk characteristics (Bradley and Roberts, 2004), the level of creditor protection (Bae and Goyal, 2009; Qian and Strahan, 2008), bankruptcy codes (Davydenko and Franks, 2008), asset redeployability (Benmelech, Garmaise, and Moskowitz, 2005; Benmelech and Bergman, 2009), corporate governance (Chava, Livdan, and Purnanandam, 2009), accounting quality (Bharath, Sunder, and Sunder, 2008), corporate mis-reporting (Graham, Li, and Qiu, 2008), asymmetric information (Ivashina, 2009), lending relationships (Bharath, Dahiya, Saunders, and Srinivasan, 2011), and the market for corporate control (Qiu and Yu, 2009).
} 


\section{The relation between competition and the cost of debt}

Does the intensity of competition affect the cost at which firms can finance their operations and investments? To address this question, I focus on a simple framework. When banks provide capital to firms and decide how to price loans, two questions are of utmost importance. First, what is the likelihood that a firm defaults while a loan is active? Second, how much of the loan face value can be recovered if a firm defaults? As such, the firm's cost of bank debt is primarily a function of a firm's default risk and the loss that banks incur when a firm defaults: ${ }^{2}$

\section{Cost of bank debt $=f$ (Default risk, Loss given default).}

Since product market competition can affect both a firm's default risk and liquidation value of assets, competition could also be a determinant of the firm's cost of bank debt. There are several reasons why competition could affect the cost of debt through the firm's default risk. First, competitive pressure reduces market power and profits. This pressure also reduces pledgeable income and increases cash flow risk, making it more difficult for borrowers to raise funds (see, for instance, Tirole, 2006, p. 283). This argument implies that for a given level of debt, promised debt yields should increase with the intensity of competition. This conjecture is consistent with recent theory and empirical evidence that show that competition increases idiosyncratic stock and cash flow volatility (Raith, 2003; Gaspar and Massa, 2006; Irvine and Pontiff, 2009). It is also in line with recent findings by Hou and Robinson (2006), who find that firms in more concentrated industries earn lower average stock returns. They argue that firms in

\footnotetext{
${ }^{2}$ The view that the firm's cost of debt is primarily a function of the firm's default risk and the asset liquidation value (loss given default) is of long standing. This framework has been widely used in structural models of credit risk (see, for instance, Merton, 1974). This perspective is also consistent with the predictions of recent dynamic corporate finance models (Fries, Miller, and Perraudin, 1997; Zhdanov, 2007). Specifically, Zhdanov (2007) shows that more intense competition increases the firm's default probability in any given period of time. At the same time, it decreases the firm's value at default. Banks rationally anticipate this “competitive risk” arising from the strategic interaction among firms and demand a higher loan spread.
} 
concentrated industries are insulated by barriers to entry, engage in less innovation, and are therefore less risky. $^{3}$

Second, firms face a constant "competitive risk" and threat of predation by rival firms. ${ }^{4}$ For instance, if firms have limited access to external funds, financially strong rivals could adopt aggressive pricing strategies that significantly increase the business risk of incumbent firms (Bolton and Scharfstein, 1990). In this spirit, Frésard (2010) provides evidence that cash-rich firms use their cash to finance competitive strategies that enhance their performance in the product market. ${ }^{5}$ Alternatively, if firms cannot fully exploit their investment opportunities, they risk losing these opportunities and market shares to competitors. This risk of underinvestment, or predation risk, has implications for corporate financing and investment choices (Haushalter, Klasa, and Maxwell, 2007). Froot, Scharfstein, and Stein (1993) argue that the interdependence of a firm's investment opportunities with product market rivals is a key determinant of predation risk. The greater this interdependence, the greater the predation risk. As such, the intensity of interactions among firms could magnify the exposure to competition and increase the likelihood that firms will not pay their interest.

But default risk is not the only possible relation between competition and the cost of debt. The alternative relation is through the liquidation value of a firm's assets (loss given default). In theory, an asset's liquidation value is the amount that creditors can expect if they seize the firm's assets and sell them on the open market (see, for instance, Harris and Raviv, 1990; Hart and Moore, 1994; Bolton and

\footnotetext{
${ }^{3}$ A counter argument to this view is that competition enforces discipline on managers and acts as a substitute for corporate governance mechanisms (e.g., Hart, 1983). In this view, competition reduces managerial slack, agency costs, and monitoring costs, and it strengthens the alignment of interests between managers and shareholders. As a consequence, firms are more profitable and less risky in competitive industries.

${ }^{4}$ I thank Laurent Frésard for pointing out this issue.

${ }^{5}$ While the implications of rivals' cash on product market outcomes seem unambiguous, the implications of rivals' financial leverage are less clear. Some studies find that debt increases firms’ aggressiveness in product markets (for instance, Campello, 2006; Lyandres, 2006), and others report that high leverage leads to poor performance in the product market (for instance, Chevalier, 1995; Phillips, 1995; Zingales, 1998; Khanna and Tice, 2000).
} 
Scharfstein, 1996). The liquidation value is of central importance when contracts are incomplete and transaction costs exist. Under such circumstances, creditors will agree to lend only if the debt is secured by the firm's assets and if default allows the creditor to recover the firm's liquidation value (collateral). Financing is, therefore, highly sensitive to the firm's liquidation value. In particular, since a higher liquidation value lowers the cost of liquidation, it increases firms' debt capacity and, in equilibrium, reduces the promised debt yield for a given debt level (Benmelech, Garmaise, and Moskowitz, 2005; Benmelech and Bergman, 2009). As a consequence, if the competitive nature of product markets impacts a firm's collateral value, competition could also affect loan spreads through this channel. For instance, competition could significantly affect the number and the financial strength of potential buyers and hence the asset liquidity of an industry (Ortiz-Molina and Phillips, 2011). As such, the structure of the product market could play an important role in determining firms’ ability to raise funds.

Taken together, theory and empirical evidence suggest that competition can be an important determinant of a bank's willingness to provide financing and of the price at which to extend it. In this paper, I build on these findings by empirically examining how competition relates to the cost of debt.

\section{Data and descriptive statistics}

\subsection{Data}

I start the sample construction with the quarterly Center for Research in Security Prices (CRSP)Compustat database and merge these data with a July 2008 extract of Loan Pricing Corporation's (LPC) Dealscan database. The LPC database contains detailed loan information for U.S. and foreign commercial loans made to government entities and corporations. Chava and Roberts (2008) provide a detailed description of the data. My sample covers the period from 1992 to 2007. I drop all loans without borrower ID (GVKEY), as well as loans that are missing information on the loan pricing, maturity, and size. ${ }^{6}$

\footnotetext{
${ }^{6}$ I acknowledge that the data do not represent a random sample of bank loans, largely because LPC's data collection procedure is skewed towards bigger firms. There is, however, no reason to believe why the sample selection should be any different for firms of the same size in competitive versus concentrated industries.
} 
I merge this data set for each three-digit SIC code industry and year with concentration ratios obtained from the Hoberg-Phillips data library and with data on international trade obtained from Peter Schott's Web site. ${ }^{7}$ Finally, I merge the data with macroeconomic data from the U.S. Bureau of Economic Analysis and the Federal Reserve Bank in St. Louis. The final data set consists of 12,256 loans for 2,900 distinct firms between 1992 and 2007 in 183 three-digit SIC code industries.

\subsection{Measuring product market competition}

My main proxy for the intensity of product market competition is the Herfindahl-Hirschman Index (HHI). A higher HHI implies weaker competition. The HHI is a widely used proxy for product market competition and well grounded in industrial organization theory (see Tirole, 1988). Specifically, I use the fitted Herfindahl-Hirschman industry concentration ratio at the three-digit SIC code industry level suggested by Hoberg and Phillips (2010a). This HHI combines Compustat data with Herfindahl data from the U.S. Commerce Department and employee data from the Bureau of Labor Statistics. As such, this HHI covers private and public firms, varies through time, and is not restricted to manufacturing firms. ${ }^{8}$ Hoberg and Phillips (2010a) describe the construction of this HHI.

To identify competitive industries, I define the dummy variable Competition, which equals one if the HHI is in the lowest quartile of the yearly sample distribution, and equals zero otherwise. This dummy variable allows for an intuitive economic interpretation of coefficient estimates. Moreover, the dummy

\footnotetext{
${ }^{7}$ I thank Gordon Phillips and Gerard Hoberg for making their product market data available online, and Robert Feenstra and Peter Schott for making their trade data publicly available.

${ }^{8}$ A common measure of industry concentration is the Herfindahl-Hirschman Index from the Census of Manufacturers. The US Census Bureau produces this index by measuring the degree of concentration in manufacturing industries and updates it every five years. Since the fitted HHI is based on the Census data, has a higher frequency, and extends to industries other than manufacturing, I prefer using this broader HHI. In an earlier version of this paper, I used the HHI from the Census of Manufacturers as the main proxy for competition.
} 
variable, as opposed to an exact value of the HHI, should mitigate measurement problems, which are sometimes an issue with the HHI.

Additionally, I take advantage of the text-based network industry classification (TNIC) provided by Hoberg and Phillips (2011). This new and dynamic industry classification is based on product descriptions from annual firm 10-K filings with the Securities and Exchange Commission (SEC), and offers an alternative to more traditional fixed industry classifications such as SIC codes and the North American Industry Classification System (NAICS). I therefore use the HHI (TNIC HHI) and the C4Index based on this variable industry classification as additional competition proxies. The C4-Index measures the market share of the four largest firms in an industry.

Finally, I also use the HHI (Compustat HHI) and C4-Index computed from Compustat data as proxies for competition. I follow the literature and compute market shares based on firms' sales (e.g., Hou and Robinson, 2006; Giroud and Mueller, 2010).

\subsection{Summary statistics}

I have an unbalanced data set and winsorize all ratios at the 1st and 99th percentiles to mitigate the impact of outliers. Panel A of Table 1 presents means, medians, and standard deviations for the loans in the sample.

\section{[Insert Table 1 about here]}

The cost of bank borrowing (the loan spread) is given by the Dealscan data item all-in-spread drawn, which is calculated as the amount the borrower pays in basis points over the London Interbank Offered Rate (LIBOR) or LIBOR equivalent for each dollar drawn. This measure adds to the borrowing spread any annual fees paid to the bank group. In the sample, the average loan spread is 178 basis points over LIBOR. The average loan maturity is between three and four years, the average loan size USD 310 million, and there are, on average, eight banks participating in a loan syndicate. Secured loans comprise 
$73 \%$ of the sample and $82 \%$ of the loans place restrictions on dividend payments. Finally, a sample loan has an average of 2.82 financial covenants.

Panel B of Table 1 shows summary statistics for the borrower firms in the sample. The average book leverage is 0.31 , the average market-to-book ratio is 1.41 , and the average asset size is USD 3.46 billion. Overall, the sample is comparable to the data in related studies (see, for instance, Chava, Livdan, and Purnanandam, 2009; Graham, Li, and Qiu, 2008; Chava and Roberts, 2008).

Panel C of Table 1 presents summary statistics for the proxies of product market competition. The HHI has an average of 0.062 and a median of 0.053 , similar to values reported by Hoberg and Phillips (2010a). The Compustat HHI is a bit larger with a sample average of 0.16, and the TNIC HHI has an average of 0.13 . Finally, Panel D of Table 1 shows the pairwise correlation coefficients between the competition proxies and loan spreads. Loan spreads correlate negatively with the HHI and the Compustat HHI, and positively with Competition.

\subsection{Empirical strategy}

To explore the relation between competition and the cost of debt, I follow Chava, Livdan, and Purnanandam (2009) and Graham, Li, and Qiu (2008) and specify the following model:

$$
y_{i, j, t}=\delta\left(\text { Competition }_{j, t-1}\right)+\beta^{\prime} X_{i, t-1}+\alpha_{t}+\eta_{j}+\varphi_{l}+\varepsilon_{i, j, t}
$$

Subscripts $i, j$, and $t$ represent the borrower, industry, and the quarter at loan issue, respectively. The dependent variable $y_{i, j, t}$ is the logarithm of the loan spread. ${ }^{9}$ My primary interest is in the marginal effect of competition on loan spreads $(\delta)$. The vector $X_{i, t-1}$ includes control variables which capture other direct and indirect sources that may correlate with loan spreads. These variables control for firms' default risk and financial distress, investment opportunities, firms' access to financing, and for aggregate

\footnotetext{
${ }^{9}$ I use the logarithm of loan spreads to address the problem of skewness in the data. Results remain virtually unchanged when I use the level of loan spreads.
} 
macroeconomic conditions. ${ }^{10}$ I also include loan type dummies $\left(\varphi_{l}\right)$, year dummies $\left(\alpha_{t}\right)$, and three-digit SIC code industry fixed effects $\left(\eta_{j}\right)$ in some specifications. I measure all control variables as of the quarter prior to the loan start date and cluster standard errors at the firm level since loans to the same firm could be correlated with each other. ${ }^{11}$

\subsection{Differences in loan spreads and firm characteristics across subsamples}

To get an initial insight on the relation between competition and loan spreads, I look at the distribution of loan spreads and firm characteristics across groups of firms based on the competition intensity and on firm size. First, Panel A of Table 2 reports average and median loan spreads for quartile portfolios of firms formed using the HHI. In each calendar year, I group observations into four groups based on the HHI. Observations with a low HHI fall into the group of firms that operate in competitive industries (Q1). Observations with a high HHI fall into the group of firms operating in non-competitive industries (Q4). The last column compares the means and medians of the first (Q1) and the fourth (Q4) quartile.

\section{[Insert Table 2 about here]}

Panel A shows that there are large differences in loan spreads between loans issued to firms operating in competitive versus concentrated industries. For instance, the average loan spread is 194 basis points for firms that operate in a competitive environment (Q1). The spread decreases monotonically from more to less competitive industries. In concentrated industries (Q4), the average loan spread is 162 basis points. The difference of 32 basis points is economically and statistically significant. For an average loan size of USD 310 million, this difference translates into an additional cost of debt of USD 992,000 per

\footnotetext{
${ }^{10}$ Throughout the analysis, I use book leverage as a proxy for financial risk. The results are very similar when I use the market leverage.

${ }^{11}$ Clustering standard errors at the three-digit SIC code industry level has no bearing on the conclusions.
} 
year. Similarly, there is a significant difference of 42.5 basis points in median loan spreads between the first and fourth quartile.

Next, in Panel B of Table 2, I additionally split each HHI quartile into two groups based on firms’ total assets (below or above the median within each HHI quartile). Panel B reports loan spreads, default and business risk proxies, and financial leverage for each group. Both small and large firms have significantly higher spreads in competitive industries. Moreover, small firms pay significantly higher loan spreads than large firms. In addition, the table shows significant differences in other firm characteristics across competitive and concentrated industries. For small firms, the leverage is significantly higher in concentrated industries (0.338) compared to competitive industries (0.307). This finding is consistent with evidence by MacKay and Phillips (2005) and in line with theories by Brander and Lewis (1986) and Maksimovic (1988). For large firms, however, this pattern reverses. Leverage is slightly higher for firms operating in more competitive environments, a pattern consistent with Bolton and Scharfstein (1990).

Competitive and concentrated industries also differ significantly along other proxies for default and business risk. Specifically, for small firms, the default probability is higher in more concentrated industries. ${ }^{12}$ For instance, while the average default probability is 0.206 in the most competitive quartile for small firms, it is 0.245 in the most concentrated quartile. This pattern could partly be explained by the higher leverage of firms in concentrated industries, as the default probability heavily depends on leverage. Alternatively, small firms are especially exposed to default risk when facing rivals in more concentrated industries. In such situations, relatively large competitors could adopt aggressive pricing strategies that significantly increase the default risk of incumbent firms (Bolton and Scharfstein, 1990). The pattern is less clear for large firms. While the average default probability is lower in the first compared to the fourth quartile, it is much higher in the second quartile compared to both the third and fourth quartile. Finally, I

\footnotetext{
${ }^{12}$ I follow Bharath and Shumway (2008) and compute the market-based probability of default (expected default frequency). Roughly speaking, this proxy for default risk is the number of standard deviations of asset growth by which a firm's market value of assets exceeds the face value of debt. Duffie, Saita, and Wang (2007) show that the expected default frequency is economically important for explaining the term structure of default probabilities.
} 
look at the cash flow volatility as a proxy for firms' business risk. For both small and large firms, cash flow volatility is significantly higher in more competitive industries, consistent with the findings of MacKay and Phillips (2005) and Irvine and Pontiff (2009). Overall, these univariate results suggest that loan spreads and proxies for default risk significantly vary across industries.

\section{Competition and the cost of debt}

\subsection{Results from panel estimations}

I study the effect of competition on the cost of debt by estimating Eq. (1). Table 3 presents the coefficient estimates. In column 1, the coefficient of Competition is 0.084 and is significant at the $1 \%$ confidence level. The effect is economically large. On average, loans to firms in competitive industries (HHI in the lowest quartile) have an $8.4 \%$ higher loan spread than comparable loans in less competitive industries. For the sample average loan spread of 178 basis points, this coefficient translates to a difference in loan spreads, between competitive and non-competitive industries, of 14.95 basis points. In cash terms, this 14.95 basis point difference corresponds to USD 463,500 of additional financing costs per year for firms in competitive industries.

[Insert Table 3 about here]

Note that the coefficients of the control variables have the expected signs. Larger firms have easier access to external finance and hence are likely to borrow from banks on better terms. I use the market-to-book ratio to proxy for firms' growth opportunities. In addition, I control for leverage (debt to total assets), profitability (EBITDA to total assets), tangibility (net property, plant, and equipment to total assets), cash flow volatility, default probability, loan size, and loan maturity. The signs of the estimated coefficients are in line with results obtained in related studies (Chava, Livdan, and Purnanandam, 2009; 
Graham, Li, and Qiu, 2008). Overall, the results suggest that small, volatile, levered firms with high default risk and few growth opportunities face higher bank financing costs. ${ }^{13}$

In column 2, I include loan type dummies and year fixed effects to capture pricing differences across loan types and unobserved time effects that could influence the cost of bank loans. While the coefficient of Competition drops slightly to 0.067 , it remains statistically and economically significant. Next, in column 3, I include three-digit SIC code industry dummies to control for time-invariant differences in risk and debt pricing across industries unrelated to competition (baseline specification). As such, this specification allows capturing the effect of within-industry changes in competition on loan spreads. The coefficient of Competition is 0.096 and statistically significant.

In columns 4 through 10, I estimate several alternative specifications to demonstrate the robustness of the main result. In particular, since credit ratings are an important determinant of bond spreads, they could also capture part of the risk arising from competition. I therefore estimate Eq. (1) by including credit rating fixed effects and report the estimates in column $4 .{ }^{14}$ The result remains virtually unchanged. The coefficient of Competition has a value of 0.094 and is statistically significant. Another potential concern relates to the banks in the sample. Some banks may systematically price loans differently than other banks in some industries, and this unobserved effect could drive the result. One way to deal with this issue is to include lender fixed effects. Column 5 presents the estimation results. The inclusion of lender fixed effects does not affect the main result; the coefficient of Competition is 0.082 and is statistically significant.

In column 6, I include other control variables that should help capture a wide range of unobservable effects. These additional control variables are the credit spread (difference between the yields of BAA and AAA corporate bonds), the term spread (difference between yields of 10-year

\footnotetext{
${ }^{13}$ I acknowledge that loan spreads can be determined simultaneously with the loan amount and loan maturity. However, when I estimate all specifications without these two control variables, I get very similar results. I therefore believe that this simultaneity is unlikely driving the results.

${ }^{14}$ The ratings go from 1 (AAA) to 20 (D). I assign the number 21 to all observations without a credit rating.
} 
Treasury bonds and 3-month T-bills), the firm's market share in the three-digit SIC code industry, the past quarterly stock return, and the $Z$-score as an additional proxy for default risk. The inclusion of these additional variables has no bearing on the result. Competition remains positive and significant.

Recent research shows that corporate governance, measured by the G-Index, relates to competition and to the pricing of equity and debt (Gompers, Ishii, and Metrick, 2003; Giroud and Mueller, 2010, 2011; Chava, Livdan, and Purnanandam, 2009). To better understand the relation between competition, governance, and loan spreads, and to minimize concerns that governance is driving the results, I include the G-Index as an additional control variable. ${ }^{15}$ In line with the findings of Chava, Livdan, and Purnanandam (2009), the coefficient of the G-Index is significantly negative, suggesting that firms with weaker corporate governance (more takeover defenses) pay lower spreads on bank loans. Competition remains, however, positive and statistically significant.

Next, I estimate the Eq. (1) using a Fama and MacBeth (1973) and a between regression approach. These alternative estimation methods allow examining cross-industry effects. Columns 8 and 9 present the results. In both columns, the coefficient of Competition is positive and statistically significant. Finally, in column 10, I directly include the HHI as a regressor in a cross-industry regression. Consistent with the results using Competition, the coefficient of the HHI is negative and significant. ${ }^{16}$

Taken as a whole, this first set of results supports the view that banks take into account the competitive environment of firms when pricing bank loans. The results also suggest that banks' assessment of firms’ competitive risk exposure is not captured by traditional proxies of firms’ default risk. In the next sections, I extend the analysis in several dimensions to support the main finding. Specifically,

\footnotetext{
${ }^{15}$ The results remain virtually unchanged when I instead control for the E-Index, as suggested by Bebchuk, Cohen, and Ferrell (2009).

${ }^{16}$ I estimate additional versions of the baseline specification by splitting the sample by time period, including firm age as an additional control variable, using quantile regressions, and controlling for self-selection. All these additional estimations do not change my conclusion and are available upon request.
} 
I use alternative industry classifications and take advantage of a quasi-natural experiment to measure exogenous changes in competition.

\subsection{Alternative proxies for product market competition}

In this section, I corroborate the main result using alternative proxies for competition. Specifically, I take advantage of the text-based industry classification (TNIC) provided by Gerard Hoberg and Gordon Phillips in their data library. The idea of this new and dynamic industry classification is the observed tendency of product market vocabulary to cluster among firms operating in the same market. Hoberg and Phillips (2011) use these data and show that these new industry measures are better at explaining the cross-section of firm characteristics. In a related paper, Hoberg and Phillips (2010b) show that mergers between firms with more similar product descriptions tend to be more successful.

Using the HHI based on this TNIC, I compute Competition (TNIC) in the same way as I do using the HHI. Each year, I rank the sample firms into quartiles and assign firms from the lowest quartile to competitive industries. ${ }^{17}$ Next, I estimate Eq. (1) with Ordinary Least Squares (OLS) and a Fama and MacBeth (1973) estimator. Columns 1 and 2 of Table 4 report the results.

[Insert Table 4 about here]

In column 1, the coefficient of Competition (TNIC) is positive and significant with a value of 0.117, suggesting that cross-industry differences in the intensity of competition significantly relate to loan spreads. This result corroborates the main finding. In column 2, I include three-digit SIC code industry fixed effects. Competition (TNIC) drops in magnitude to 0.03 but remains significant at the $6 \%$ confidence level. In columns 3 and 4, I use the C4-Index based on the TNIC. The C4-Index measures the market share held by the four largest firms in the industry. As such, it is a measure of industry concentration, and higher values indicate a more concentrated industry. In columns 3 and 4, C4-Index

\footnotetext{
${ }^{17}$ The results are robust to using the continuous version of this HHI (not reported).
} 
(TNIC) is negative and significant, suggesting that firms in more concentrated industries pay lower loan spreads, consistent with the results in this paper.

Finally, I also use the HHI and C4-Index based on Compustat data and estimate Eq. (1) with and without industry fixed effects. Columns 5 through 8 present the results. Competition (Compustat) relates positively to loan spreads while the C4-Index (Compustat) relates negatively. Overall, these additional results show that the main result is robust to alternative industry definitions and measures of competition.

\subsection{Why is default risk not a sufficient statistic for the effect of competition?}

In Section 2, I emphasize that default risk is likely to be an important statistic for the effect of competition on loan spreads. As a consequence, the specifications in Tables 3 and 4 include proxies for default and financial risk. For instance, leverage partly captures default risk. Similarly, cash flow volatility, the default probability, and the $Z$-score could all control for other dimensions of default risk. However, despite these control variables, the effect of competition on loan spreads remains positive. This finding suggests that traditional proxies of firms' default risk do not entirely capture banks' assessment of a firm's “competitive risk” exposure. One possible reason for the persistence of the positive effect of competition on loan spreads could be that the proxies for default risk are only imperfect and hence do not entirely capture the effect of competition. I minimize this possibility by using several different default risk proxies. An alternative reason could be that competition has both an industry-wide and a within-industry effect, and that competition does not only affect default risk, but also other dimensions that are crucial for the pricing of corporate debt, such as firms' exposure to predatory behavior and firms' collateral value. As such, the risk arising from the competitive environment is a broader concept of risk that goes above and beyond default risk. This interpretation is in line with the univariate tests in Table 2. Moreover, this interpretation is also consistent with the results in Section 6 of this paper which suggest that the effect of competition is significantly larger when small firms face relatively large rivals, when the liquidation value of assets is low, or when predatory risk is high. 


\section{Endogeneity of product market competition}

The results so far show that firms operating in competitive industries pay significantly higher loan spreads compared to firms operating in more concentrated industries. A potential concern, however, relates to the endogeneity of product market competition. Firms could genuinely affect the intensity of competition they face from rival firms. For instance, firms could use their financial structure to influence product market outcomes by hurting their rivals’ profitability and driving rivals into insolvency (e.g., Brander and Lewis, 1986; Bolton and Scharfstein, 1990). Indeed, empirical evidence suggests that firms strategically use their financing policy to affect the structure of product markets. ${ }^{18}$ As such, industry structure and financing decisions are jointly determined. I address this problem in this section.

\subsection{The quasi-natural experiment: reductions of import tariff rates}

To address the potential endogeneity of product market competition, I examine the response of loan spreads to unexpected variations of industry import tariff rates in a quasi-natural experiment setting. According to the vast literature on barriers to trade, the globalization of economic activities and trade openness imply that firms are increasingly exposed to foreign rivals (Bernard, Jensen, and Schott, 2006). The general consensus of this literature is that lower trade barriers trigger a significant increase in competition from foreign rivals (Tybout, 2003). Indeed, reductions of import tariff rates significantly decrease the cost of entering U.S. product markets and increase the presence of goods and services from foreign rivals on domestic markets. This penetration of imports spurs an increase in the competitive pressure that domestic producers face. Recently, several papers take advantage of tariff rate reductions as an exogenous shock to the competitive environment. ${ }^{19}$

I therefore follow Frésard (2010) and use large reductions of import tariff rates as events that trigger a sudden increase in the competitive pressure faced by foreign rivals. I gather U.S. import data compiled by Feenstra (1996), Feenstra, Romalis, and Schott (2002), and Schott (2010) for my sample

\footnotetext{
${ }^{18}$ For a survey, see Cestone (1999).

${ }^{19}$ See, for instance, Trefler (2004), Guadalupe and Wulf (2010), or Frésard (2010).
} 
period 1992 to $2005 .^{20}$ The match of these import data with my sample results in 5,331 loans for 1,372 distinct firms in 96 three-digit SIC code industries.

For each industry-year, I compute the ad valorem tariff rate as the duties collected at U.S. Customs divided by the Free-On-Board custom value of imports. Next, I characterize "competitive shocks" as large variations in the tariff rate in terms of the deviation of the yearly change in tariff rates from the same industry's median or average change. To do so, I first compute for each industry the median (average) tariff rate change as well as the largest tariff rate change. These average and median changes of tariff rates are negative (see Table 1, Panel C). Next, I identify all industries in which the largest tariff rate reduction is larger than three times the median (average) tariff rate reduction in that industry. ${ }^{21}$ To make sure that the tariff rate reductions truly reflect non-transitory changes in the competitive environment, I exclude tariff rate reductions that are preceded and followed by equivalently large increases in tariff rates. Based on these calculations, I define for each industry the dummy variable Post-reduction $_{j, t}$ which equals one if the tariff rate reduction (competitive shock) has occurred in industry $j$ by time $t$.

With this definition, I identify 54 large tariff rate reductions in 54 distinct three-digit SIC code industries between 1992 and 2005. Fig. 1 shows how these reductions are distributed over the sample period. Thirty of them occurred in 1995, which coincides with the creation of a trade block between the U.S., Canada, and Mexico in 1994 (North American Free Trade Agreement (NAFTA)). But note that there are also some large reductions in the later 1990s. This repartition of tariff rate reductions over the sample period minimizes the concern that the identification is driven by a time-specific event that happened during a given year.

\footnotetext{
${ }^{20}$ These data only exist for manufacturing industries.

${ }^{21}$ In my sample, 42 industries never experience a large tariff rate reduction. These industries serve as "control” industries. By contrast, 12 industries experience more than one tariff rate reduction larger than three times the median rate reduction in that industry. For these industries, I identify the largest tariff rate reduction as the event. Excluding these industries has no bearing on the results.
} 


\subsection{Empirical method}

To investigate the effect of large shifts of import tariff rates on loan spreads, I follow Graham, Li, and Qiu (2008) and Santos (2011) and estimate the following model of loan spreads:

$$
y_{i, j, t}=\lambda\left(\text { Post-reduction }_{j, t}\right)+\beta^{\prime} X_{i, t-1}+\eta_{j}+\varphi_{l}+\varepsilon_{i, j, t} .
$$

As in model (1), subscripts $i, j$, and $t$ represent the borrower, industry, and the quarter at loan issue, respectively. The dependent variable $y_{i, j, t}$ is the logarithm of the loan spread. The vector $X_{i, t-1}$ includes control variables capturing other direct and indirect sources that correlate with loan spreads. The variable Post-reduction $_{j, t}$ is a dummy variable that equals one if industry $j$ has experienced a tariff rate reduction by year $t$ that is larger than three times the median tariff rate reduction in industry $j$, and zero otherwise. I also include loan type dummies $\left(\varphi_{l}\right)$ and three-digit SIC code industry fixed effects $\left(\eta_{j}\right)$ in the estimations. The industry fixed effects are necessary to identify the within-industry change in loan spreads when competition intensifies, keeping everything else constant. The estimate of the competitive shock's effect is $\lambda$, the coefficient of Post-reduction ${ }_{j, t}$. This approach allows comparing the change in loan spreads of firms in industries that do experience a competitive shock to the change in loan spreads of firms in industries that do not experience a competitive shock. ${ }^{22}$

${ }^{22}$ Note that this approach is similar to the approach used by Bertrand and Mullainathan (2003) to examine the effect of a takeover legislation on firm-level outcomes. Specifically, suppose that I want to estimate the effect of the large tariff rate reduction in the "Electronic components and accessories” industry (SIC 367) in 1995 on loan spreads. I would subtract loan spreads after 1995 from loan spreads before 1995 for all firms in that industry. But other things could have affected these firms in 1995, such as a recession. Choosing a control industry, for example, industry SIC 221 (“Broadwoven fabric mills, cotton”), helps to control for changing economic conditions. I would therefore compare the difference in loan spreads in industry SIC 367 before and after 1995 to the difference in loan spreads in industry SIC 221 before and after 1995. The difference of these two differences would serve as an estimate of the competitive shock's effect in industry SIC 367. The important difference between this example and model (2) is that model (2) accounts for the fact that the competitive shocks are distributed over time. As such, the control 
The key advantage of using tariff rate reductions is that they provide sufficient time series and cross-industry variations to identify the effect of a competitive shock on loan spreads. To ensure a proper identification of the causal effect of tariff rate reductions on loan spreads, this empirical design needs to meet two requirements. First, the tariff rate reductions should bring relevant real-side changes to the competitive nature of product markets. Second, the source of variation that shifts the competitive environment should be exogenous to industry financing and partly unanticipated by firms. Appendix B provides supportive evidence for these requirements. Specifically, over the sample period, the average tariff rate drops from 3\% one year prior to the tariff rate reduction to below $1.5 \%$ afterwards. At the same time, this tariff rate decrease is accompanied by a substantial increase of import penetration from 19.5\% to $24.1 \%$. Moreover, the comparison of the financing policies of firms that are affected by a competitive shock with the financing policies of firms that are not affected reveals no systematic differences prior to a large tariff rate reduction. This finding suggests that these tariff rate reductions are partly unanticipated. In addition, while diverse interest groups may have an influence on trade policy through lobbying activity, there is no obvious reason why industries would lobby for a reduction of import tariff rates. Overall, these analyses mitigate concerns about the endogeneity of tariff rate reductions to firms' financing policies.

\subsection{Tariff rate reductions and loan spreads: univariate tests}

Table 5 offers a first look at the question of whether loan spreads are affected by tariff rate reductions. Specifically, the table reports average loan spreads and firm characteristics before and after a competitive shock for small (total assets below sample median) and large firms. Panel A shows that loan spreads increase by 21.6 basis points in the aftermath of a tariff rate reduction for small firms. This increase is economically and statistically significant. At the same time, we observe a significant increase

group is not restricted to industries that never experience a competitive shock. It implicitly takes as the control group all firms from industries not experiencing a competitive shock at time $t$, even if they have already experienced a shock or will experience one later on. 
in the default probability and cash flow volatility. For large firms, the increase in loan spreads is even greater (Panel B). Loan spreads increase by 39.8 basis points when a competitive shock hits the industry. Again, this increase in loan spreads is accompanied by a significant increase in the default probability. Note that the leverage slightly increases after a competitive shock for large firms, but does not significantly change for small firms. Overall, these univariate results suggest that a higher competitive pressure from foreign rivals leads to an increase in firms’ loan spreads. In the following, I investigate whether this finding continues to hold in a multivariate setting.

\section{[Insert Table 5 about here]}

\subsection{Tariff rate reductions and loan spreads: multivariate tests}

Table 6 presents the estimation results from Eq. (2). In the benchmark case, Post-reduction $_{j, t}$ is equal to one if the tariff rate reduction is at least three times larger than the median tariff rate reduction in that industry. In column 1, the coefficient of Post-reduction $_{j, t}$ has a value of 0.169 and is positive and significant. In column 2, I include loan type and industry fixed effects to capture the effect of a withinindustry change in competition on loan spreads. Post-reduction $n_{j, t}$ is significantly positive with a value of 0.22. This estimate suggests that banks ask for $22 \%$ higher loan spreads in the aftermath of a competitive

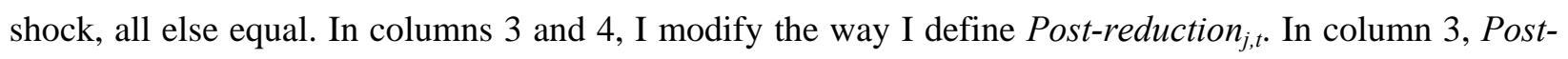
reduction $_{j, t}$ equals one if the tariff rate reduction is two times larger than the median tariff rate reduction in that industry. In column 4, Post-reduction ${ }_{j, t}$ equals one if the tariff rate reduction is three times larger than the average tariff rate reduction in that industry. In both columns, Post-reduction $_{j, t}$ is positive and statistically significant. In all, the results in Table 6 substantiate the main findings that a higher intensity of competition significantly increases loan spreads.

[Insert Table 6 about here] 


\subsection{Additional tests}

In this section I estimate additional specifications to support the robustness of the results. In particular, I control for aggregate time effects, selection biases, and dynamic effects. Table 7 reports these estimation results. In column 1, I follow Graham, Li, and Qiu (2008) and include variables that should help to control for macroeconomic cycles. These variables include the credit spread, the term spread, real GDP growth, and a dummy variable equal to one if the loan was initiated between 1996 and 2000. Postreduction $_{j, t}$ remains significantly positive with a value of 0.154 . In column 2 , I include firm fixed effects. In this specification, the effect of competition on loan spreads is identified only by the changes in loan spreads within firms that took out loans both before and after a competitive shock. This approach also alleviates concerns about sample selection, such as potential unobserved differences between firms that did and firms that did not take out bank loans after a significant tariff rate reduction. The coefficient of Post-reduction $_{j, t}$ has a value of 0.183 and is statistically significant. Next, in column 3 I include firm and year fixed effects to control for time-invariant differences between firms and for aggregate fluctuations. ${ }^{23}$ The coefficient of Post-reduction $_{j, t}$ drops to 0.08 but remains economically and statistically significant.

\section{[Insert Table 7 about here]}

If the effect of a competitive shock is too large, some firms may not want to borrow after a large tariff rate reduction. As such, a sample selection bias is a potential concern. Although the inclusion of a firm fixed effect alleviates this concern, I perform two additional tests. First, I estimate Eq. (2) and only include refinancing loans. The Dealscan database explicitly specifies "whether or not the current deal refinances a prior deal”. Thus, by focusing on these refinancing loans, I can effectively exclude "new" loans from the sample and focus on loans that refinance an earlier loan. This restriction should help to

\footnotetext{
${ }^{23}$ This specification is essentially a difference-in-differences approach along the lines of Bertrand and Mullainathan (2003).
} 
minimize the concern about the selection bias. Second, I restrict the sample to firms that had at least one loan before and at least one loan after the competitive shock. The results of these two additional specifications are in columns 4 and 5. In both columns, the coefficient of Post-reduction $_{j, t}$ is positive and significant.

A next concern relates to issues of reverse causality. Although reverse causality is unlikely to be a major problem in this case, as discussed in Appendix B, I study in greater detail the dynamic effects of tariff rate reductions on loan spreads. I follow Bertrand and Mullainathan (2003) and replace the Postreduction $_{j, t}$ dummy with four dummy variables: Before $^{-1}$ is a dummy variable equal to one for an industry that will experience a tariff rate reduction one year prior to the event, Before $e^{0}$ is a dummy variable equal to one for an industry experiencing a tariff rate reduction in that year, After $^{l}$ is a dummy variable equal to one for an industry that experienced a tariff rate reduction last year, and $A f t e r^{2+}$ is a dummy variable equal to one for an industry that experienced the tariff rate reduction at least two years ago. If the dummy variable Before $^{-1}$ is positive and significant, it would be an indication of reverse causation. The estimated coefficients in column 6 reveal that Before ${ }^{-1}$ and Before $e^{0}$ are insignificantly different from zero. Moreover, the coefficients of $\mathrm{After}^{1}$ and $\mathrm{After}^{2+}$ are positive and statistically significant, while the coefficient of After $^{2+}$ is economically larger than After $^{l}$ (0.349 compared to 0.22). These results dispel concerns about reverse causality and further corroborate the main findings.

Next, I follow Giroud and Mueller (2010) and directly use the percent produced by international vs. domestic firms (import penetration) as a proxy for product market competition. I estimate Eq. (2) by replacing Post-reduction $_{j, t}$ with import penetration. The coefficient of Import penetration is significantly positive in column 7, suggesting that increased international competition relates positively to loan spreads, confirming the results using import tariff rates.

Finally, I perform change regressions in which I regress the change in loan spreads on the change in import tariff rates. This approach allows to further control for omitted firm-level variables that are constant through time. Note, however, that this approach significantly reduces the sample size. First, I need to restrict the sample to firms that issued a loan of the same type before and after a competitive 
shock. Second, if a firm issued multiple loans before or after a tariff rate reduction, I only keep the last loan of each type before and the first loan of each type after the tariff rate reduction. I am left with 422 loans after this filtering. ${ }^{24}$ Next, I compute the change in the logarithm of loan spreads, the change in the tariff rate ( $\Delta$ Tariff rate), and changes in firm characteristics.

\section{[Insert Table 8 about here]}

Table 8 presents the results of the change regressions. The coefficient of $\Delta$ Tariff rate is significantly negative in columns 1 and 2, suggesting that increases in loan spreads go along with decreases in tariff rates. These results are consistent with the analysis above and suggest that the results are not driven by omitted variable biases.

\subsection{Cross-sectional differences in the effect of tariff rate reductions}

In this section I explore the cross-sectional nature of the sample to further characterize the effects of a competitive shock on firms' cost of debt and to support the validity of the quasi-natural experiment. Specifically, if reductions of import tariff rates truly facilitate the entrance of foreign rivals, the competitive effect of tariff rate reductions will presumably be larger in more concentrated industries in which new firms are expected to enter. Similarly, the effect of a tariff rate reduction should be strongest in industries that experience the largest inflow of foreign rivals. Finally, firms in industries that are protected by other barriers to entry should be in a better position to withstand the effects of a tariff rate reduction.

To test these predictions, I split the industries affected by a tariff rate reduction based on four variables, estimate Eq. (2) for these subsamples, and compare the estimates across the subsamples. I measure industry concentration using the HHI. To proxy for the inflow of foreign rivals, I compute the

\footnotetext{
${ }^{24}$ This procedure is analogous to those used by Chava, Livdan, and Purnanandam (2009) and Santos (2011), resulting in a similar number of loans.
} 
average change in import penetration for each industry. A large positive change in import penetration indicates a higher inflow of foreign rivals and hence an increased competitive pressure for domestic firms. Finally, I use two variables to proxy for other barriers to entry. First, Sutton (1991) and Shaked and Sutton (1987) suggest that firms can use $R \& D$ and advertising expenses to differentiate their products from those of competitors. This product differentiation makes it more expensive and difficult for rivals to enter an industry and to compete with these firms. As such, high R\&D and advertising expenses allow firms to build endogenous barriers to entry. ${ }^{25}$ On this ground, I use lagged average R\&D and advertising expenses in proportion to sales as a proxy for barriers to entry. The second proxy is the lagged average cash holdings to total asset ratio of incumbent firms. Cash holdings of incumbent firms could affect rivals' decisions to enter an industry because a firm's stock of cash can signal the possibility of aggressive behavior and therefore distort rivals’ actions in the product market (Benoit, 1984). Moreover, cash-rich firms can use their cash to finance competitive strategies to the detriment of rivals' future prospects (Bolton and Scharfstein, 1990).

For each year and for each proxy, I rank the sample industries according to their average value and assign firms from industries in the bottom and top quartiles to "low" and "high" industries, respectively. Next, for each proxy, I estimate Eq. (2) across subgroups via a seemingly unrelated regression system (SUR) and compare the estimates of Post-reduction ${ }_{j, t}$ across low and high industries.

[Insert Table 9 about here]

Table 9 reports which firms are most affected by a tariff rate reduction. For brevity, I only display the estimates of Post-reduction ${ }_{j, t}$. The results in row 1 show that the effect of a tariff rate reduction is larger in concentrated industries. For instance, while the coefficient of Post-reduction $_{j, t}$ is 0.126 in competitive industries, the coefficient increases to 0.416 in concentrated industries. A Wald test rejects

\footnotetext{
${ }^{25}$ Hoberg and Phillips (2011) test Sutton's (1991) theory of endogenous barriers to entry and find that firms spending more on either advertising or R\&D experience significant reductions in measures of ex post competition.
} 
the equality of coefficients across subgroup estimations. This result suggests that an increase in the competitive pressure from foreign rivals mostly affects firms in concentrated industries that are insulated from foreign competitors by high import tariff rates. Similarly, the effect of a competitive shock is significantly larger in industries that experience large positive changes in import penetration (row 2). This result lends further support to the argument that import tariff rate reductions indeed trigger an intensification of competition from foreign firms. Next, in rows 3 and 4 , the effect of a tariff rate reduction is larger when other barriers to entry are low. For instance, the coefficient of Post-reduction ${ }_{j, t}$ is $50 \%$ larger when advertising and R\&D expenses are low. Similarly, the coefficient of Post-reduction $_{j, t}$ is almost twice as large when incumbent firms have low levels of cash. These results are in line with the idea that firms are especially exposed to trade shocks when they cannot protect themselves with other entry barriers such as product differentiation or large cash holdings. In all, these ancillary results corroborate the main findings and further support the validity of the quasi-natural experiment.

\section{Differences in the effect of competition across industries}

Hitherto, I find evidence that an increased intensity of competition significantly increases the cost of debt. To further understand the nature and potential drivers of this result, I explore under which circumstances product market competition matters most for loan spreads. Specifically, I ask whether the effect of competition depends on the difference between firms' and rivals' financial strength, on the quantity of interactions between firms within industries, and on the asset specificity and illiquidity of an industry.

\subsection{Firms' and rivals' financial strength}

I start by investigating whether the effect of competition depends on the competitive position of a firm with respect to its rivals. In particular, I look at whether the effect of competition is more pronounced in industries in which financially weak firms face financially strong rivals. To examine this prediction, I estimate the effect of competition when small firms or firms without a credit rating face large firms or 
rivals with high credit ratings. To do so, I rank in each year firms with an asset size below the sample median or unrated firms according to the average rivals' size or credit rating and assign firms from industries below and above the median to low and high industries, respectively. ${ }^{26}$ For each proxy, I then separately estimate the baseline model (Eq. (1)) across subgroups with and without industry fixed effects and compare the estimates of Competition $(\delta)$ across low and high groups. ${ }^{27}$

\section{[Insert Table 10 about here]}

Table 10 reports in which industries "competitive risk" is more prevalent. For brevity, I only report the estimated coefficients of Competition. Across both proxies for the difference in financial strength, the effect of competition is larger when industry rivals have a relatively stronger financial position. For instance, row 1 presents the results for small firms facing small and large rivals, respectively. The coefficient estimate of Competition is almost zero for the subgroup in which small firms face small competitors. For the subgroup in which small firms face large rivals, however, the coefficient of Competition is 0.151 and statistically significant. A Wald test rejects the equality of the Competition coefficients across the two subgroups. The result is comparable when examining cross-industry effects. Moreover, I obtain a similar pattern when I split industry-years on the basis of rivals' credit ratings. The effect of competition is higher when unrated firms face rivals with a high credit rating. These findings are in line with Bolton and Scharfstein (1990) who argue that financially strong rivals can adopt aggressive competitive strategies to increase the business risk of incumbent firms.

\footnotetext{
${ }^{26}$ I compute rivals' financial strength by excluding the firm itself.

${ }^{27}$ I estimate the specification with industry fixed effects via a seemingly unrelated regression system (see column 3 in Table 3), and the specification without industry fixed effects using a Fama and MacBeth (1973) estimator (see column 8 in Table 3).
} 


\subsection{Intensity of strategic interactions between firms}

Next, I examine whether the effect of competition depends on the intensity with which firms interact in their product market (predation risk). I use two proxies for the quantity of interactions between firms. The first proxy is the degree of industry concentration. Kovenock and Phillips (1997) and Zingales (1998) show that strategic interactions are more prevalent in more concentrated industries. Therefore, in each year, I rank the sample industries (three-digit SIC code) according to the Compustat C4-Index, and assign firms from industries in the lowest and highest quartiles to low and high industries, respectively. As a second proxy, I look at whether a firm operates at the technological core or on the fringe of its industry. As in MacKay and Phillips (2005), I define the industry technology as the median capital-labor ratio for a given industry-year and compute the similarity of operations as the absolute deviation between a firm's capital-labor ratio and its industry median for this ratio. To make this difference comparable across industries, I scale it by the industry range of the capital-labor ratio. Smaller values of this proxy indicate a greater similarity between a firm's operations and the operations of industry counterparts and therefore potentially a greater predation risk.

The rows 3 and 4 of Table 10 reveal that the effect of competition tends to be larger when firms operate in industries with more strategic interactions. For example, the effect of competition is more than three times as large when a firm operates in a highly concentrated market. The results are similar for cross-industry estimates. Moreover, a Wald test ( $t$-test) rejects the equality of the Competition coefficients across the two subgroups. The results for the similarity of operations proxy are slightly weaker. But overall, the results suggest that the amount of strategic interactions within industries and hence predation risk could play a potentially important role for the pricing of “competitive risk”.

\subsection{Specificity and illiquidity of industry assets}

In this section I analyze whether the effect of competition depends on the specificity and illiquidity of industry assets. First, following Stromberg (2001) and Acharya, Bharath, and Srinivasan (2007), I measure asset specificity as the average book value of machinery and equipment divided by the 
book value of total assets at the three-digit SIC code industry level. Second, to proxy for illiquid industry conditions, I use several proxies. The first proxy is the average of the inverse of the quick ratio, measured as current assets to current liabilities (Acharya, Bharath, and Srinivasan, 2007). For the second proxy, I follow Ortiz-Molina and Phillips (2011) and use the average book leverage net of cash of rival firms. This proxy should capture the financial slack of potential buyers. Finally, I use the number of rival firms in the industry that have a credit rating (e.g., Benmelech and Bergman, 2009; Ortiz-Molina and Phillips, 2011). A lower number of rivals indicates a higher illiquidity. In each year and for each proxy, I classify firms from industries in the bottom and top quartiles as low and high industries, respectively, and estimate Eq. (1) for the subgroups with and without industry fixed effects.

\section{[Insert Table 11 about here]}

Table 11 reports the results for the estimated coefficients of Competition. Irrespective of the proxy, the estimates suggest that competition has a differential impact depending on the specificity and illiquidity of industry assets. For instance, row 1 shows that the coefficient of Competition is almost three times as large in industries with specific assets. Next, rows 2, 3, and 4 reveal that the effect of competition is significantly larger in industries characterized by high asset illiquidity. These differences are more significant for cross-industry estimates than for within-industry estimates. Taken together, while OrtizMolina and Phillips (2011) find that asset liquidity is an important determinant for the firm's cost of capital in competitive industries, the analysis in this section provides evidence on the interaction between asset liquidity, competition, and the firm's cost of debt. In particular, the results suggest that “competitive risk" translates into higher loan spreads when the liquidation value of assets is likely to be low.

\section{Conclusion}

This paper provides evidence linking product market competition to spreads of bank loans. The main finding is that firms operating in competitive environments have significantly higher costs of debt 
financing. This effect of competition is magnified when financially weak firms face financially strong rivals, when firms interact more intensely with each other, and when the industry's assets are specific and illiquid. Using tariff rate reductions as an exogenous competitive shock in a quasi-natural experiment setting, the paper shows that the result is unlikely driven by endogenous product market competition.

Overall, the results emphasize the importance of taking into account the linkages between product and financial markets. In this spirit, the findings point to several interesting avenues for future research. First, in this paper, I do not explore the precise channel through which competition affects the cost of debt, as such analysis is beyond the scope of this paper. The results suggest, however, that industry characteristics that relate to firms' default risk, investment opportunities, and liquidation value play an important role in explaining that link.

Second, the results in this paper emphasize that the intensity of competition is a fundamental determinant of a firm's cost of bank debt. The results point to potential competition externalities and spillover effects among industry peers that need to be considered when evaluating a firm's financing cost. While recent research shows that firms' capital structure decisions depend on industry structure and industry peers (for instance, Bradley, Jarrell, and Kim, 1984; MacKay and Phillips, 2005; Leary and Roberts, 2010), it would be interesting to gain a deeper understanding about product market feedbacks, and how these feedbacks ultimately affect financial contracts and firms’ real investment decisions.

Third, while understanding how product market competition affects debt pricing is important, it does not shed any light on how firms should adjust their financing policy in the presence of competition. For instance, what security should firms issue given the competition they face? In light of the results in this paper, the competitive environment could be an important determinant of a firm's choice to issue equity, bank debt, or public debt. I look forward to additional research in these and related areas. 


\section{Appendix A}

Definition of variables

This table provides definitions of the main variables. Compustat data are from the quarterly Compustat database. Loan contract data are from Loan Pricing Corporation's Dealscan database. Data on bond yields are from the Federal Reserve Board of Governors. Tariff data are from Robert Feenstra's and Peter Schott's Web page, and Herfindahl data are from the Hoberg-Phillips data library.

\begin{tabular}{|c|c|}
\hline$H H I$ & $\begin{array}{l}\text { Herfindahl-Hirschman Index at the three-digit SIC code industry level based on Hoberg } \\
\text { and Phillips (2010a). This HHI combines Compustat data with Herfindahl data from the } \\
\text { Commerce Department and employee data from the Bureau of Labor Statistics, covers } \\
\text { private and public firms, and all industries. }\end{array}$ \\
\hline Competition & $\begin{array}{l}\text { Dummy variable equal to one if the } \mathrm{HHI} \text { is in the lowest quartile of the yearly sample } \\
\text { distribution, and zero otherwise. }\end{array}$ \\
\hline Compustat HHI & $\begin{array}{l}\text { Herfindahl-Hirschman Index computed using Compustat firms. It is defined as the sum } \\
\text { of squared market shares. Market shares are computed using firms' sales. }\end{array}$ \\
\hline C4-Index & The sum of the market shares of the four largest firms in an industry. \\
\hline TNIC HHI & $\begin{array}{l}\text { Herfindahl-Hirschman Index based on the text-based network industry classification } \\
\text { (TNIC) based on Hoberg and Phillips (2011). }\end{array}$ \\
\hline Post-reduction $_{j, t}$ & $\begin{array}{l}\text { Dummy variable equal to one if industry } j \text { has experienced a tariff reduction that is } \\
\text { three times larger than the median tariff rate reduction in that industry at time } t \text {, and } \\
\text { zero otherwise. }\end{array}$ \\
\hline Import penetration & $\begin{array}{l}\text { Total value of imports divided by total value of imports plus domestic production at the } \\
\text { three-digit SIC code industry level. }\end{array}$ \\
\hline Loan spread & $\begin{array}{l}\text { Loan spread is measured as all-in-spread drawn in the Dealscan database. It is defined } \\
\text { as the amount the borrower pays in basis points over LIBOR or LIBOR equivalent for } \\
\text { each dollar drawn down. This measure adds the borrowing spread of the loan over } \\
\text { LIBOR with any annual fee paid to the bank group. }\end{array}$ \\
\hline Loan size & Loan facility amount divided by total assets. \\
\hline Loan maturity & Loan maturity measured in months. \\
\hline Total assets & Total book assets in billions USD. \\
\hline Leverage & (Debt in current liabilities + total long-term debt) divided by total assets. \\
\hline Market-to-book & $\begin{array}{l}\text { (Debt in current liabilities }+ \text { total long-term debt }+ \text { preferred stock carrying value }- \\
\text { deferred taxes and investment tax credit }+ \text { stock price at the end of quarter } \times \text { common } \\
\text { shares outstanding) divided by total assets. }\end{array}$ \\
\hline Profitability & EBITDA divided by total assets. \\
\hline Tangibility & Net property, plant, and equipment divided by total assets. \\
\hline Cash flow volatility & $\begin{array}{l}\text { Ratio of the standard deviation of the past eight earnings changes to the average book } \\
\text { asset size over the past eight quarters. }\end{array}$ \\
\hline Default probability & Estimate of firm’s default probability along the lines of Bharath and Shumway (2008). \\
\hline Z-score & $\begin{array}{l}1.2 \times(\text { current assets }- \text { current liabilites }) / \text { total assets }+1.4 \times(\text { retained earnings } / \text { total assets }) \\
+3.3 \times(\text { pretax income } / \text { total assets })+0.6 \times(\text { market capitalization/ total liabilities })+ \\
0.9 \times(\text { sales/total assets }) \text {. }\end{array}$ \\
\hline Credit spread & The difference between AAA corporate bond yield and BAA corporate bond yield. \\
\hline Term spread & The difference between the 10-year Treasury yield and the T-bill yield. \\
\hline Asset specificity & Proportion of machinery and equipment to total assets. \\
\hline Asset illiquidity & 1/[(Cash and short-term investment + total receivables) divided by current liabilities]. \\
\hline Similarity of operations & $\begin{array}{l}\text { Absolute value of the difference between a firm's ratio of net plant and equipment per } \\
\text { employee and the median ratio in its industry, scaled by the industry range of the } \\
\text { capital-labor ratio. }\end{array}$ \\
\hline Market share & Sales divided by total Compustat sales in the three-digit SIC code industry. \\
\hline Stock return & Quarterly stock return. \\
\hline Net leverage of rivals & Leverage net of cash of rivals in the same three-digit SIC code industry. \\
\hline $\begin{array}{l}\text { Number of potential } \\
\text { buyers }\end{array}$ & $\begin{array}{l}\text { The number of competitors in the same three-digit SIC code industry with a credit } \\
\text { rating. }\end{array}$ \\
\hline
\end{tabular}




\section{Appendix B. Import tariff rate reductions as a quasi-natural experiment}

This appendix provides figures and descriptive statistics supporting the use of tariff rate reductions as a quasi-natural experiment. In particular, the appendix first shows that import tariff rate reductions are accompanied by a significant increase of imports by foreign firms. Second, the appendix shows that firms do not change their financing policies in anticipation of tariff rate reductions.

The idea of using tariff rate reductions as a measure of increased competitive pressure rests on the observation that lower tariff rates make it less costly for foreign rivals to compete on domestic markets. The resulting entrance of foreign rivals increases the intensity of product market competition. To verify that a relaxation of tariffs spurs an increase in import penetration, I follow Bertrand (2004) and Irvine and Pontiff (2009) and define import penetration as the total value of imports divided by imports plus domestic production. This variable measures the percent produced by foreign versus domestic firms, or alternatively, the aggregate market share of foreign competitors. Fig. B1 displays the event-time evolution of the average import tariff rate and import penetration for industries that experience a tariff rate reduction larger than three times the median tariff rate reduction in each industry between 1992 and 2005. The figure shows that the import tariff rate drops from $3 \%$ one year before the tariff rate reduction to $1.42 \%$ one year after the tariff rate reduction. Over the same time window, import penetration increases significantly from $19.5 \%$ to $24.1 \%$. This large increase is in line with evidence from the trade literature (e.g., Bernard, Jensen, and Schott, 2006; Trefler, 1993; Lee and Swagel, 1997) and supports the intuition that lower import tariff rates indeed facilitate the entrance of foreign rivals and increase the intensity of competition for domestic firms.

Second, large import tariff rate reductions should be exogenous to firms’ financing decisions. In other words, it should be difficult for firms to fully endogenize the competitive shock by lowering, for instance, their leverage before the tariff reductions in order to keep default risk constant. To evaluate this possibility, I follow Frésard (2010) and examine the firms' financing policies surrounding tariff rate reductions. Specifically, Fig. B2 shows the event-time pattern of affected firms' average leverage and cash-to-asset ratios. This figure suggests that these firms do not experience systematic changes in their 
debt and cash levels prior to large tariff rate reductions. Next, I compare the average and median of these three financial variables of firms in industries that will experience a tariff rate reduction over the next year (54 industries) with the average and median of firms in industries that never experience a tariff rate reduction over the sample period (42 industries). Notably, Table B1 suggests that industries experiencing tariff reductions are generally comparable with industries that do not experience significant tariff changes. Indeed, the numbers reveal no systematic difference in the firms' average and median levels of debt. Although firms in affected industries tend to hold slightly more cash than firms not affected by a tariff rate reduction, the difference seems economically rather small. These descriptive statistics corroborate the result in column 6 of Table 7 in the main text, which reveals no anticipation effects prior to a competitive shock. Overall, these results minimize concerns that firms optimally chose their financing policy beforehand to deal with the consequences of an increased competitive pressure. 


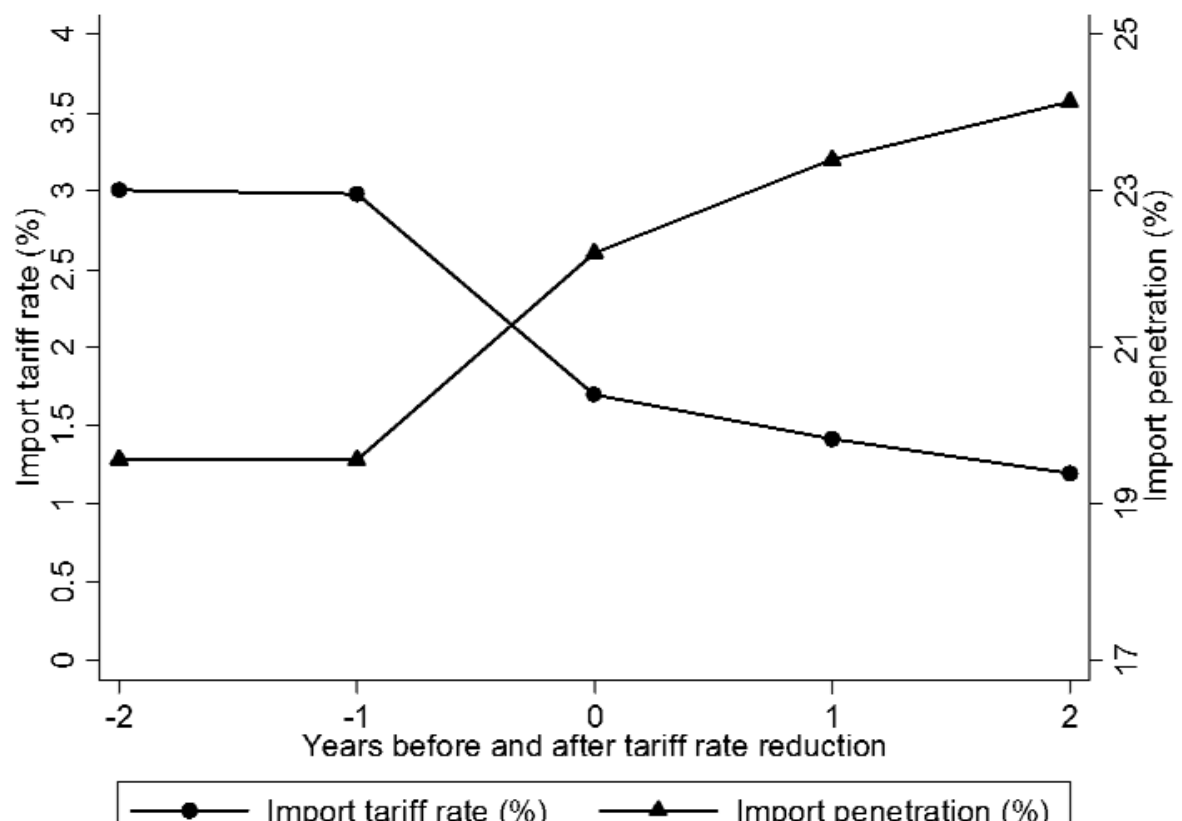

Fig. B1. Tariff rates and import penetration around large tariff rate reductions. This figure shows the average import tariff rate and import penetration surrounding the years of large tariff rate reductions. Tariff rates are computed at the three-digit SIC code industry level as duties collected at U.S. Customs divided by the Free-On-Board custom value of imports. An industry experiences a large tariff rate reduction if the reduction is at least three times larger than the median tariff rate reduction in that industry. Import penetration is computed at the three-digit SIC code industry level as total imports divided by domestic production plus total imports. 


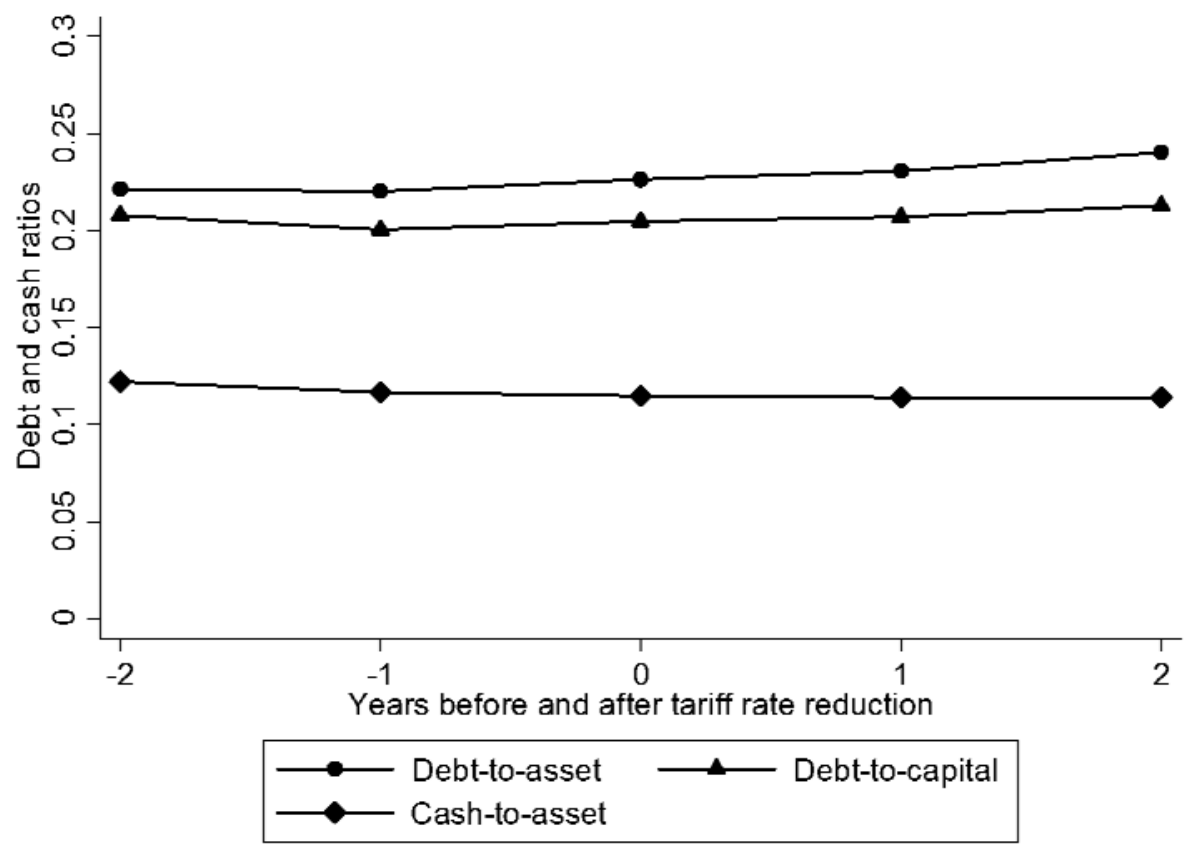

Fig. B2. Evolution of firms' financing policies around tariff rate reductions. This figure shows the event-time evolution of the average leverage (debt-to-asset and debt-to-capital) and cash-to-asset ratios surrounding the years of large tariff rate reductions. Tariff rates are computed at the three-digit SIC code industry level as duties collected at U.S. Customs divided by the Free-On-Board custom value of imports. An industry experiences a large tariff rate reduction if the reduction is at least three times larger than the median tariff rate reduction in that industry. 


\section{Table B1}

Descriptive statistics for industries that do and do not experience a large tariff rate reduction

This table reports the averages of firm characteristics and the number of industry-year observations (italicized) for industries that will experience a large tariff rate reduction over the next year and for industries that never experience a large tariff rate reduction over the sample period 1992 to 2005. An industry experiences a large tariff rate reduction if the reduction is at least three times larger than the median or mean tariff rate reduction in that industry. Significance of the difference between affected and not affected industries at the $10 \%, 5 \%$, and $1 \%$ level is indicated by $*, * *$, and $* * *$, respectively.

\begin{tabular}{lcccc}
\hline & \multicolumn{2}{c}{$a b s(\Delta$ Tariff $)>3 \times$ median } & \multicolumn{2}{c}{ abs $(\Delta$ Tariff) $>3 \times$ mean } \\
Variable & Affected & Not affected & Affected & Not affected \\
\hline \multirow{2}{*}{ Leverage } & 0.319 & 0.332 & 0.319 & 0.328 \\
& 550 & 406 & 391 & 565 \\
Market leverage & 0.312 & 0.329 & & \\
& 550 & 406 & 391 & 565 \\
& & & & 0.326 \\
Cash-to-asset ratio & $0.055^{* *}$ & 0.048 & $0.061^{* * *}$ & 0.046 \\
& 550 & 406 & 391 & 565 \\
\hline
\end{tabular}




\section{References}

Acharya, V., Bharath, S., Srinivasan, A., 2007. Does industry-wide distress affect defaulted firms? Evidence from creditor recoveries. Journal of Financial Economics 85, 787-821.

Aghion, P., Bolton, P., 1992. An incomplete contracts approach to financial contracting. Review of Economic Studies 59, 473-494.

Bae, K.-H., Goyal, V., 2009. Creditor rights, enforcement, and bank loans. Journal of Finance 64, 823860.

Bebchuk, L., Cohen, A., Ferrell, A., 2009. What matters in corporate governance? Review of Financial Studies 22, 783-827.

Benmelech, E., Bergman, N., 2009. Collateral pricing. Journal of Financial Economics 91, 339-360.

Benmelech, E., Garmaise, M., Moskowitz, T., 2005. Do liquidation values affect financial contracts? Evidence from commercial loan contracts and zoning regulation. Quarterly Journal of Economics 120, 1121-1154.

Benoit, J.-P., 1984. Financially constrained entry in a game with incomplete information. Rand Journal of Economics 15, 490-499.

Bernard, A., Jensen, B., Schott, P., 2006. Trade costs, firms, and productivity. Journal of Monetary Economics 53, 917-937.

Bertrand, M., Mullainathan, S., 2003. Enjoying the quiet life? Corporate governance and managerial preferences. Journal of Political Economy 111, 1043-1075.

Bertrand, M., 2004. From the invisible handshake to the invisible hand? How import competition changes the employment relationship. Journal of Labor Economics 22, 723-765.

Bharath, S., Dahiya, S., Saunders, A., Srinivasan, A., 2011. Lending relationships and loan contract terms. Review of Financial Studies 24, 1141-1203.

Bharath, S., Shumway, T., 2008. Forecasting default with the Merton distance to default model. Review of Financial Studies 21, 1339-1369. 
Bharath, S., Sunder, J., Sunder, S., 2008. Accounting quality and debt contracting. Accounting Review 83, 1-28.

Bolton, P., Scharfstein, D., 1990. A theory of predation based on agency problems in financial contracting. American Economic Review 80, 93-106.

Bolton, P., Scharfstein, D., 1996. Optimal debt structure and the number of creditors. Journal of Political Economy 104, 1-26.

Bradley, M., Roberts, M., 2004. The structure and pricing of corporate debt covenants. Unpublished working paper. Duke University and University of Pennsylvania.

Bradley, M., Jarrell, G., Kim, H., 1984. On the existence of an optimal capital structure: theory and evidence. Journal of Finance 39, 857-878.

Brander, J., Lewis, T., 1986. Oligopoly and financial structure: the limited liability effect. American Economic Review 76, 956-970.

Campello, M., 2006. Debt financing: does it boost or hurt firm performance in product markets? Journal of Financial Economics 82, 135-172.

Cestone, G., 1999. Corporate financing and product market competition: an overview. CSEF Working Paper No. 18.

Chava, S., Livdan, D., Purnanandam, A., 2009. Do shareholder rights affect the cost of bank loans? Review of Financial Studies 22, 2973-3004.

Chava, S., Roberts, M., 2008. How does financing impact investment? The role of debt covenants. Journal of Finance 63, 2085-2121.

Chevalier, J., 1995. Do LBO supermarkets charge more? An empirical analysis of the effects of LBOs on supermarkets’ pricing. Journal of Finance 50, 1095-1112.

Davydenko, S., Franks, J., 2008. Do bankruptcy codes matter? A study of defaults in France, Germany, and the U.K. Journal of Finance 63, 565-608.

Duffie, D., Saita, L., Wang, K., 2007. Multi-period corporate default prediction with stochastic covariates. Journal of Financial Economics 83, 635-665. 
Fama, E., MacBeth, J., 1973. Risk, return, and equilibrium: empirical tests. Journal of Political Economy 81, 607-636.

Feenstra, R., 1996. U.S. imports, 1972-1994: data and concordances. NBER Working Paper No. 5515.

Feenstra, R., Romalis, J., Schott, P., 2002. U.S. imports, exports, and tariff data, 1989-2001. NBER Working Paper No. 9387.

Frésard, L., 2010. Financial strength and product market behavior: the real effects of corporate cash holdings. Journal of Finance 65, 1097-1122.

Fries, S., Miller, M., Perraudin, W., 1997. Debt in industry equilibrium. Review of Financial Studies 10, 39-67.

Froot, K., Scharfstein, D., Stein, J., 1993. Risk management: coordinating corporate investment and financing policies. Journal of Finance 48, 1629-1658.

Gaspar, J.-M., Massa, M., 2006. Idiosyncratic volatility and product market competition. Journal of Business 79, 3125-3152.

Giroud, X., Mueller, H., 2010. Does corporate governance matter in competitive industries? Journal of Financial Economics 95, 312-331.

Giroud, X., Mueller, H., 2011. Corporate governance, product market competition, and equity prices. Journal of Finance 66, 563-600.

Gompers, P., Ishii, J., Metrick, A., 2003. Corporate governance and equity prices. Quarterly Journal of Economics 118, 107-155.

Graham, J., Li, S., Qiu, J., 2008. Corporate misreporting and bank loan contracting. Journal of Financial Economics 89, 44-61.

Guadalupe, M., Wulf, J., 2010. The flattening firm and product market competition: the effect of trade liberalization on corporate hierarchies. American Economic Journal: Applied Economics 2, 105127.

Harris, M., Raviv, A., 1990. Capital structure and the informational role of debt. Journal of Finance 45, 321-349. 
Hart, O., 1983. The market mechanism as an incentive scheme. Bell Journal of Economics 14, 366-382.

Hart, O., Moore, J., 1994. A theory of debt based on the inalienability of human capital. Quarterly Journal of Economics 109, 841-879.

Haushalter, D., Klasa, S., Maxwell, W., 2007. The influence of product market dynamics on a firm’s cash holding and hedging behavior. Journal of Financial Economics 84, 797-825.

Hoberg, G., Phillips, G., 2010a. Real and financial industry booms and busts. Journal of Finance 65, 4586.

Hoberg, G., Phillips, G., 2010b. Product market synergies and competition in mergers and acquisitions: a text-based analysis. Review of Financial Studies 23, 3773-3811.

Hoberg, G., Phillips, G., 2011. Text-based network industries and endogenous product differentiation. Unpublished working paper, University of Maryland.

Hou, K., Robinson, D., 2006. Industry concentration and average stock returns. Journal of Finance 61, 1927-1956.

Irvine, P., Pontiff, J., 2009. Idiosyncratic return volatility, cash flows, and product market competition. Review of Financial Studies 22, 1149-1177.

Ivashina, V., 2009. Asymmetric information effects on loan spreads. Journal of Financial Economics 92, 300-319.

Khanna, N., Tice, S., 2000. Strategic response of incumbents to new entry: the effect of ownership structure, capital structure, and focus. Review of Financial Studies 13, 749-779.

Kovenock, D., Phillips, G., 1997. Capital structure and product market behavior: an examination of plant exit and investment decisions. Review of Financial Studies 10, 767-803.

Leary, M., Roberts, M., 2010. Do peer firms affect corporate financial policy? Unpublished working paper. Washington University at St. Louis and University of Pennsylvania.

Lee, J.-W., Swagel, P., 1997. Trade barriers and trade flows across countries and industries. Review of Economics and Statistics 79, 372-382. 
Lyandres, E., 2006. Capital structure and interaction among firms in output market: theory and evidence. Journal of Business 79, 2381-2421.

MacKay, P., Phillips, G., 2005. How does industry affect firm financial structure? Review of Financial Studies 18, 1433-1466.

Maksimovic, V., 1988. Capital structure in repeated oligopolies. Rand Journal of Economics 19, 389407.

Merton, R., 1974. On the pricing of corporate debt: the risk structure of interest rates. Journal of Finance 29, 449-470.

Morellec, E., Nikolov, B., 2008. Cash holdings and competition. Unpublished working paper. University of Rochester.

Ortiz-Molina, H., Phillips, G., 2011. Asset liquidity and the cost of capital. Unpublished working paper. University of Maryland.

Peress, J., 2010. Product market competition, insider trading, and stock market efficiency. Journal of Finance 65, 1-43.

Phillips, G., 1995. Increased debt and industry product markets: an empirical analysis. Journal of Financial Economics 37, 189-238.

Qian, J., Strahan, P., 2008. How laws and institutions shape financial contracts: the case of bank loans. Journal of Finance 62, 2803-2834.

Qiu, J.,Yu, F., 2009. The market for corporate control and the cost of debt. Journal of Financial Economics 93, 505-524.

Raith, M., 2003. Competition, risk, and managerial incentives. American Economic Review 93, 14251436.

Santos, J., 2011. Bank corporate loan pricing following the subprime crisis. Review of Financial Studies 24, 1916-1943.

Schott, P., 2010. U.S. manufacturing exports and imports by SIC and NAICS category and partner country, 1972-2005. Unpublished working paper. Yale School of Management. 
Shaked, A., Sutton, J., 1987. Product differentiation and industrial structure. Journal of Industrial Economics 26, 131-146.

Stromberg, P., 2001. Conflicts of interest and market illiquidity in bankruptcy auctions: theory and tests. Journal of Finance 55, 2641-2692.

Sutton, J., 1991. Sunk Costs and Market Structure. MIT Press, Cambridge, MA.

Tirole, J., 1988. The Theory of Industrial Organization. MIT Press, Cambridge, MA.

Tirole, J., 2006. The Theory of Corporate Finance. Princeton University Press, Princeton and Oxford.

Trefler, D., 1993. Trade liberalization and the theory of endogenous protection: an econometric study of U.S. import policy. Journal of Political Economy 101, 138-160.

Trefler, D., 2004. The long and short of the Canada-U.S. Free Trade Agreement. American Economic Review 94, 870-985.

Tybout, J., 2003. Plant-and firm-level evidence on “new” trade theories. In: Choi, K., Harrigan, J. (Eds.), Handbook of International Trade, Basil-Blackwell, Oxford, 388-415.

Xu, J., 2011. Product market competition and capital structure: evidence from import penetration. Journal of Financial Economics, forthcoming.

Zhdanov, A., 2007. Competitive equilibrium with debt. Journal of Financial and Quantitative Analysis 42, $649-672$.

Zingales, L., 1998. Survival of the fittest or fattest? Exit and financing in the trucking industry. Journal of Finance 53, 905-938. 


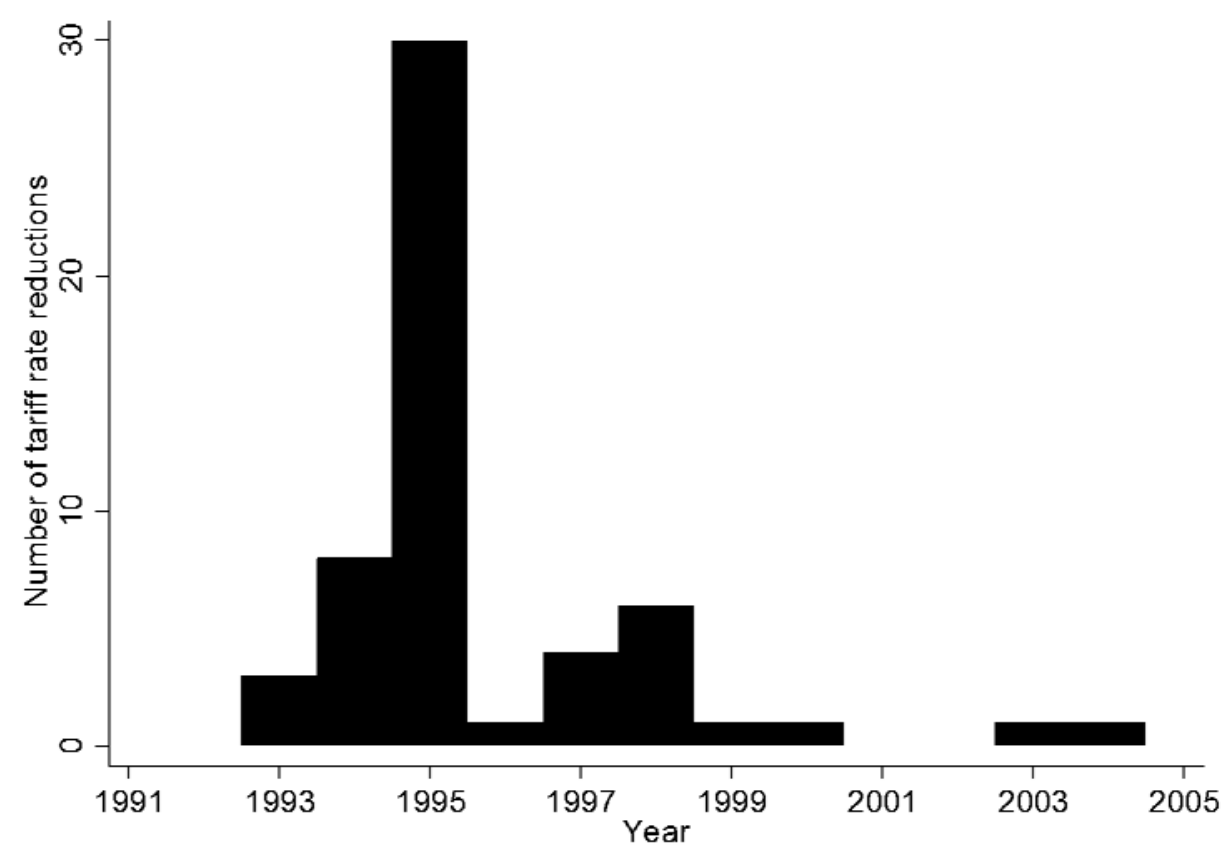

Fig. 1. Distribution of tariff rate reductions through time. This figure shows the number of tariff rate reductions for each year during the sample period 1992 to 2005. Tariff rates are computed at the three-digit SIC code industry level as duties collected at U.S. Customs divided by the Free-On-Board custom value of imports. An industry experiences a tariff rate reduction if the reduction is at least three times larger than the median tariff rate reduction in that industry. 
Table 1

Summary statistics

This table presents summary statistics for loans, borrowers, and for proxies of product market competition. Panel A presents means, medians, and standard deviations of loan characteristics. Panel B shows summary statistics of borrower characteristics. Panel C presents summary statistics of competition proxies. Finally, Panel D shows the correlation coefficients between loan spreads and the competition proxies. The sample period is from 1992 to 2007. All variables are defined in Appendix A. Significance at the 10\%, 5\%, and 1\% level is indicated by *, **, and ***, respectively.

Panel A: Loan characteristics

\begin{tabular}{lrrrrrr}
\hline & N & Mean & Median & SD & Min & Max \\
\hline Loan spread (basis points) & 12,256 & 178.38 & 150 & 127.16 & 17.5 & 580 \\
Loan maturity (months) & 12,256 & 44.04 & 45 & 23.82 & 11 & 121 \\
Loan size (million USD) & 12,256 & 310 & 115 & 509 & 0.85 & 2800 \\
Loan size (to total assets) & 12,256 & 0.18 & 0.13 & 0.17 & 0.01 & 0.98 \\
Syndicate size & 12,251 & 8.05 & 5 & 8.72 & 1 & 45 \\
Secured dummy & 8,638 & 0.73 & 1 & 0.44 & 0 & 1 \\
Dividend restriction dummy & 7,815 & 0.82 & 1 & 0.38 & 0 & 1 \\
No. of financial covenants & 7,525 & 2.82 & 3 & 1.19 & 1 & 7 \\
\hline
\end{tabular}

Panel B: Borrower characteristics

\begin{tabular}{lrrrrrr}
\hline & $\mathrm{N}$ & Mean & Median & SD & Min & Max \\
\hline Total assets (billion USD) & 12,256 & 3.46 & 0.71 & 6.89 & 0.00 & 34.46 \\
Leverage & 12,256 & 0.31 & 0.29 & 0.2 & 0 & 0.96 \\
Profitability & 12,256 & 0.03 & 0.03 & 0.03 & -0.18 & 0.13 \\
Market-to-book & 12,256 & 1.41 & 1.13 & 1.01 & 0.32 & 8.44 \\
Tangibility & 12,256 & 0.34 & 0.28 & 0.24 & 0.01 & 0.9 \\
Cash flow volatility & 12,256 & 0.02 & 0.01 & 0.02 & 0 & 0.15 \\
Default probability & 12,256 & 0.17 & 0 & 0.31 & 0 & 1
\end{tabular}

Panel C: Product market competition proxies

\begin{tabular}{lrrrrrr}
\hline & $\mathrm{N}$ & Mean & Median & SD & Min & Max \\
\hline HHI & 12,256 & 0.062 & 0.053 & 0.028 & 0.032 & 0.224 \\
Competition & 12,256 & 0.260 & 0 & 0.439 & 0 & 1 \\
Compustat HHI & 12,256 & 0.161 & 0.126 & 0.136 & 0 & 0.937 \\
TNIC HHI & 9,301 & 0.131 & 0.092 & 0.118 & 0 & 0.939 \\
$\Delta$ Tariff & 5,331 & -0.133 & -0.062 & 0.361 & -4.057 & 2.929 \\
\hline
\end{tabular}

Panel D: Correlation coefficients

\begin{tabular}{|c|c|c|c|c|c|c|}
\hline & $\begin{array}{l}\text { Log(loan } \\
\text { spread) }\end{array}$ & Fitted HHI & Competition & $\begin{array}{c}\text { Compustat } \\
\text { HHI }\end{array}$ & TNIC HHI & $\Delta$ Tariff \\
\hline Log(loan spread) & 1.00 & & & & & \\
\hline$H H I$ & $-0.106^{* * *}$ & 1.00 & & & & \\
\hline Competition & $0.096^{* * *}$ & $-0.476^{* * *}$ & 1.00 & & & \\
\hline Compustat HHI & $-0.051^{* * *}$ & $0.391^{* * *}$ & $-0.316^{* * *}$ & 1.00 & & \\
\hline TNIC HHI & $0.052^{* * *}$ & $-0.071^{* * *}$ & $0.046^{* * *}$ & $0.025^{* *}$ & 1.00 & \\
\hline$\Delta$ Tariff & $-0.057^{* * *}$ & $0.129^{* * *}$ & $-0.065^{* * *}$ & $0.051^{* * *}$ & 0.021 & 1.00 \\
\hline
\end{tabular}


Table 2

Loan spreads and firm characteristics across quartiles of HHI and firm size

This table presents average loan spreads and firm characteristics for quartile portfolios of firms formed using the Herfindahl-Hirschman Index (HHI) at the three-digit SIC code industry level from Hoberg and Phillips (2010a). This HHI combines Compustat data with Herfindahl data from the US Commerce Department and employee data from the Bureau of Labor Statistics, covers private and public firms, and all industries. Higher values of the HHI are associated with lower levels of competition. In Panel A, I sort firms each calendar year based on the HHI and assign the firms into quartiles. Next, I compute average and median loan spreads for each quartile. The last column reports the difference in means and medians between competitive (Q1) and concentrated (Q4) industries. In Panel B, I additionally split firms into small and large firms within each HHI quartile based on total assets (below or above median, respectively) and report the averages of proxies for financial, default, and cash flow risk. I compute the statistical significance of the difference in means with a mean comparison $t$-test, and the difference in medians with a Wilcoxon rank-sum test. The sample period is from 1992 to 2007. All variables are defined in Appendix A. Significance at the $10 \%, 5 \%$, and $1 \%$ level is indicated by $*, * *$, and $* * *$, respectively.

Panel A: Loan spreads for quartile portfolios based on the HHI

\begin{tabular}{lrrrrr}
\hline & $\mathrm{Q} 1$ & $\mathrm{Q} 2$ & $\mathrm{Q} 3$ & $\mathrm{Q} 4$ & $\mathrm{Q} 1-\mathrm{Q} 4$ \\
\hline Average loan spread & 194.09 & 187.03 & 169.31 & 162.28 & $31.81^{* * *}$ \\
Median loan spread & 175.00 & 175.00 & 150.00 & 132.50 & $42.50^{* * *}$ \\
Average number of loans & & & & & \\
\hline
\end{tabular}

Panel B: Loan spreads and firm characteristics for quartile portfolios based on the HHI and total assets

\begin{tabular}{|c|c|c|c|c|c|}
\hline Small firms & Q1 & Q2 & Q3 & Q4 & Q1-Q4 \\
\hline Loan spread & 253.85 & 240.78 & 228.49 & 211.92 & $41.93^{* * *}$ \\
\hline Leverage & 0.307 & 0.332 & 0.335 & 0.338 & $-0.031^{* * *}$ \\
\hline Default probability & 0.206 & 0.211 & 0.210 & 0.245 & $-0.039^{* * *}$ \\
\hline Cash flow volatility & 0.027 & 0.024 & 0.022 & 0.021 & $0.006^{* * *}$ \\
\hline Large firms & Q1 & Q2 & Q3 & Q4 & $\mathrm{Q} 1-\mathrm{Q} 4$ \\
\hline Loan spread & 134.32 & 133.32 & 110.13 & 112.47 & $21.85^{* * *}$ \\
\hline Leverage & 0.349 & 0.367 & 0.334 & 0.331 & $0.018^{* * *}$ \\
\hline Default probability & 0.113 & 0.187 & 0.136 & 0.145 & $-0.032^{* * *}$ \\
\hline Cash flow volatility & 0.014 & 0.011 & 0.013 & 0.012 & $0.002^{* * *}$ \\
\hline
\end{tabular}




\section{Table 3}

Competition and the cost of debt: panel results

This table presents coefficient estimates of regressions which examine the effect of competition on loan spreads (Eq. (1)). The dependent variable is the logarithm of loan spreads. Competition is a dummy variable equal to one if the HHI at the three-digit SIC code industry level is in the lowest quartile of the yearly sample distribution, and zero otherwise. Column 1 presents the results without any fixed effects. Column 2 includes loan type and year fixed effects, and column 3 includes industry fixed effects at the three-digit SIC code industry level. Column 4 includes credit rating fixed effects, and column 5 lender fixed effects. In column 6, I include additional control variables. Column 7 controls for governance using the G-Index. In columns 8 and 9, I estimate Eq. (1) using a Fama and MacBeth (1973) and between industry estimator, respectively. Finally, column 10 directly includes the HHI as a proxy for competition. Lower values of the HHI indicate more competitive industries. I measure all independent variables as of the quarter prior to the loan start date. The sample period is from 1992 to 2007. All variables are defined in Appendix A. I report $t$-statistics using standard errors adjusted for within-firm clustering (OLS) or for one lag serial correlation (Fama and MacBeth) in parentheses below the coefficient estimates. Significance at the $10 \%$, 5\%, and $1 \%$ level is indicated by $*$, **, and $* * *$, respectively.

\begin{tabular}{|c|c|c|c|c|c|c|c|c|c|c|}
\hline & $\begin{array}{l}\text { No fixed } \\
\text { effects }\end{array}$ & $\begin{array}{l}\text { Loan type } \\
\text { and year }\end{array}$ & $\begin{array}{c}\text { Baseline } \\
\text { (SIC3) }\end{array}$ & $\begin{array}{l}\text { Credit } \\
\text { Ratings }\end{array}$ & Lenders & $\begin{array}{c}\text { Other } \\
\text { controls }\end{array}$ & G Index & $\begin{array}{c}\text { Fama- } \\
\text { MacBeth }\end{array}$ & $\begin{array}{l}\text { Between } \\
\text { regression }\end{array}$ & $H H I$ \\
\hline Variables & $(1)$ & $(2)$ & (3) & $(4)$ & (5) & (6) & $(7)$ & $(8)$ & $(9)$ & $(10)$ \\
\hline Competition & $\begin{array}{c}0.084^{* * *} \\
(3.62)\end{array}$ & $\begin{array}{c}0.067^{* * *} \\
(3.46)\end{array}$ & $\begin{array}{c}0.096^{* * *} \\
(3.00)\end{array}$ & $\begin{array}{c}0.094^{* * * *} \\
(2.94)\end{array}$ & $\begin{array}{l}0.082^{* *} \\
(2.52)\end{array}$ & $\begin{array}{l}0.079^{* *} \\
(2.45)\end{array}$ & $\begin{array}{c}0.109^{* *} \\
(2.07)\end{array}$ & $\begin{array}{c}0.068^{* * * *} \\
(4.20)\end{array}$ & $\begin{array}{c}0.070^{* *} \\
(1.96)\end{array}$ & \\
\hline$H H I$ & & & & & & & & & & $\begin{array}{c}-0.602^{* *} \\
(-2.54)\end{array}$ \\
\hline Log(total assets) & $\begin{array}{c}-0.280^{* * *} \\
(41.91)\end{array}$ & $\begin{array}{c}-0.268^{* * *} \\
(39.58)\end{array}$ & $\begin{array}{c}-0.284^{* * * *} \\
(43.76)\end{array}$ & $\begin{array}{l}-0.228^{* * *} \\
(34.57)\end{array}$ & $\begin{array}{l}-0.271^{* * *} \\
(37.17)\end{array}$ & $\begin{array}{c}-0.247^{* * *} \\
(32.51)\end{array}$ & $\begin{array}{l}-0.332^{* * *} \\
(28.92)\end{array}$ & $\begin{array}{l}-0.275^{* * *} \\
(27.86)\end{array}$ & $\begin{array}{c}-0.107^{* * *} \\
(4.25)\end{array}$ & $\begin{array}{c}-0.273^{* * *} \\
(27.74)\end{array}$ \\
\hline Market-to-book & $\begin{array}{c}-0.095^{* * *} \\
(7.99)\end{array}$ & $\begin{array}{c}-0.095^{* * *} \\
(9.42)\end{array}$ & $\begin{array}{c}-0.081^{* * * *} \\
(8.66)\end{array}$ & $\begin{array}{c}-0.065^{* * *} \\
(7.59)\end{array}$ & $\begin{array}{c}-0.083^{* * *} \\
(9.00)\end{array}$ & $\begin{array}{c}-0.093^{* * * *} \\
(8.01)\end{array}$ & $\begin{array}{c}-0.109^{* * *} \\
(6.53)\end{array}$ & $\begin{array}{c}-0.124^{* * *} \\
(8.91)\end{array}$ & $\begin{array}{c}-0.089^{* *} \\
(2.43)\end{array}$ & $\begin{array}{l}0.036^{* *} \\
(2.48)\end{array}$ \\
\hline Leverage & $\begin{array}{l}0.859^{* * *} \\
(14.25)\end{array}$ & $\begin{array}{l}0.734^{* * *} \\
(14.17)\end{array}$ & $\begin{array}{l}0.712^{* * * *} \\
(13.83)\end{array}$ & $\begin{array}{l}0.517^{* * *} \\
(10.70)\end{array}$ & $\begin{array}{c}0.706^{* * *} \\
(13.53)\end{array}$ & $\begin{array}{l}0.761^{* * *} \\
(12.00)\end{array}$ & $\begin{array}{c}0.801^{* * *} \\
(9.89)\end{array}$ & $\begin{array}{l}0.833^{* * *} \\
(16.92)\end{array}$ & $\begin{array}{l}0.500^{*} \\
(1.82)\end{array}$ & $\begin{array}{l}0.567^{* * *} \\
(11.64)\end{array}$ \\
\hline Tangibility & $\begin{array}{l}-0.070 \\
(1.50)\end{array}$ & $\begin{array}{l}0.030 \\
(0.75)\end{array}$ & $\begin{array}{c}-0.298^{* * *} \\
(4.88)\end{array}$ & $\begin{array}{c}-0.205^{* * *} \\
(3.91)\end{array}$ & $\begin{array}{c}-0.295^{* * *} \\
(4.88)\end{array}$ & $\begin{array}{c}-0.356^{* * *} \\
(5.84)\end{array}$ & $\begin{array}{c}-0.190^{*} \\
(1.79)\end{array}$ & $\begin{array}{l}0.025 \\
(0.81)\end{array}$ & $\begin{array}{l}0.064 \\
(0.77)\end{array}$ & $\begin{array}{l}0.068^{* *} \\
(2.31)\end{array}$ \\
\hline Cash flow volatility & $\begin{array}{l}0.575 \\
(1.17)\end{array}$ & $\begin{array}{l}0.558 \\
(1.38)\end{array}$ & $\begin{array}{l}0.186 \\
(0.47)\end{array}$ & $\begin{array}{l}0.779^{* *} \\
(2.07)\end{array}$ & $\begin{array}{l}0.044 \\
(0.11)\end{array}$ & $\begin{array}{l}0.322 \\
(0.79)\end{array}$ & $\begin{array}{l}1.871^{* *} \\
(2.40)\end{array}$ & $\begin{array}{c}1.131^{* * *} \\
(2.95)\end{array}$ & $\begin{array}{l}0.432 \\
(0.24)\end{array}$ & $\begin{array}{c}1.290^{* * *} \\
(3.76)\end{array}$ \\
\hline Default probability & $\begin{array}{l}0.458^{* * * *} \\
(11.33)\end{array}$ & $\begin{array}{l}0.363^{* * *} \\
(10.09)\end{array}$ & $\begin{array}{c}0.356^{* * *} \\
(9.67)\end{array}$ & $\begin{array}{l}0.333^{* * *} \\
(10.73)\end{array}$ & $\begin{array}{c}0.316^{* * *} \\
(8.50)\end{array}$ & $\begin{array}{l}0.394^{* * *} \\
(10.80)\end{array}$ & $\begin{array}{l}0.587^{* * *} \\
(11.01)\end{array}$ & $\begin{array}{c}0.342^{* * *} \\
(9.59)\end{array}$ & $\begin{array}{c}0.359^{* *} \\
(2.01)\end{array}$ & $\begin{array}{l}0.051^{*} \\
(1.73)\end{array}$ \\
\hline
\end{tabular}




\begin{tabular}{|c|c|c|c|c|c|c|c|c|c|c|}
\hline Profitability & $\begin{array}{l}-3.337^{* * *} \\
(10.96)\end{array}$ & $\begin{array}{c}-2.899^{* * *} \\
(10.93)\end{array}$ & $\begin{array}{l}-2.660^{* * *} \\
(10.99)\end{array}$ & $\begin{array}{l}-2.542^{* * *} \\
(11.19)\end{array}$ & $\begin{array}{c}-2.047^{* * *} \\
(8.20)\end{array}$ & $\begin{array}{l}-2.936^{* * *} \\
(11.84)\end{array}$ & $\begin{array}{c}-3.329^{* * *} \\
(5.63)\end{array}$ & $\begin{array}{l}-3.363^{* * *} \\
(12.81)\end{array}$ & $\begin{array}{c}-5.181^{* * *} \\
(3.20)\end{array}$ & $\begin{array}{l}-2.854^{* * *} \\
(10.82)\end{array}$ \\
\hline Loan size & $\begin{array}{c}-0.552^{* * *} \\
(8.77)\end{array}$ & $\begin{array}{c}-0.332^{* * *} \\
(5.35)\end{array}$ & $\begin{array}{c}-0.405^{* * *} \\
(5.73)\end{array}$ & $\begin{array}{c}-0.376^{* * *} \\
(5.87)\end{array}$ & $\begin{array}{c}-0.359^{* * *} \\
(5.25)\end{array}$ & $\begin{array}{c}-0.418^{* * *} \\
(5.92)\end{array}$ & $\begin{array}{c}-0.407^{* * *} \\
(5.32)\end{array}$ & $\begin{array}{c}-0.268^{* * *} \\
(5.66)\end{array}$ & $\begin{array}{c}0.893^{* *} \\
(2.22)\end{array}$ & $\begin{array}{c}-0.275^{* * *} \\
(5.66)\end{array}$ \\
\hline Log(loan maturity) & $\begin{array}{l}0.141^{* * *} \\
(11.09)\end{array}$ & $\begin{array}{c}-0.065^{* * *} \\
(4.20)\end{array}$ & $\begin{array}{c}-0.049^{* * *} \\
(3.26)\end{array}$ & $\begin{array}{c}-0.067^{* * *} \\
(4.67)\end{array}$ & $\begin{array}{c}-0.050^{* * *} \\
(3.23)\end{array}$ & $\begin{array}{c}-0.063^{* * *} \\
(4.03)\end{array}$ & $\begin{array}{c}-0.059^{* *} \\
(2.17)\end{array}$ & $\begin{array}{l}-0.019 \\
(0.94)\end{array}$ & $\begin{array}{c}-0.639^{* * *} \\
(4.42)\end{array}$ & $\begin{array}{c}-0.055^{\text {*** }} \\
(3.16)\end{array}$ \\
\hline Credit spread & & & & & & $\begin{array}{l}0.493^{* * *} \\
(13.99)\end{array}$ & & & & \\
\hline Term spread & & & & & & $\begin{array}{l}0.010^{*} \\
(1.78)\end{array}$ & & & & \\
\hline Market share & & & & & & $\begin{array}{c}-0.531^{* * *} \\
(4.90)\end{array}$ & & & & \\
\hline Stock return & & & & & & $\begin{array}{c}0.001^{* * *} \\
(3.18)\end{array}$ & & & & \\
\hline$Z$-score & & & & & & $\begin{array}{c}0.011^{* * *} \\
(2.63)\end{array}$ & & & & \\
\hline G-Index & & & & & & & $\begin{array}{c}-0.011^{* *} \\
(2.04)\end{array}$ & & & \\
\hline Loan type fixed effects & No & Yes & Yes & Yes & Yes & Yes & Yes & Yes & Yes & Yes \\
\hline Year fixed effects & No & Yes & Yes & Yes & Yes & No & Yes & No & No & No \\
\hline Industry fixed effects & No & No & Yes & Yes & Yes & Yes & Yes & No & No & No \\
\hline Estimation method & OLS & OLS & OLS & OLS & OLS & OLS & OLS & $\begin{array}{c}\text { Fama } \\
\text { MacBeth }\end{array}$ & $\begin{array}{l}\text { Between } \\
\text { regression }\end{array}$ & $\begin{array}{c}\text { Fama } \\
\text { MacBeth }\end{array}$ \\
\hline Observations & 12,256 & 12,256 & 12,256 & 12,256 & 12,251 & 11,171 & 5,868 & 12,256 & 12,256 & 12,256 \\
\hline Adjusted/average/between $R^{2}$ & 0.55 & 0.64 & 0.68 & 0.73 & 0.70 & 0.67 & 0.70 & 0.66 & 0.78 & 0.70 \\
\hline
\end{tabular}




\section{Table 4}

Competition and the cost of debt: alternative industry definitions and proxies for competition

This table presents coefficient estimates of regressions which examine the effect of competition on loan spreads (Eq. (1)). The dependent variable is the logarithm of loan spreads. Competition is a dummy variable equal to one if the HHI is in the lowest quartile of the yearly sample distribution, and zero otherwise. Columns 1 and 2 present the results using the HHI based on the text-based network industry classification (TNIC) following Hoberg and Phillips (2011). Columns 3 and 4 show the results using the C4-Index based on the TNIC. Columns 5 and 6 present the results using the HHI based on Compustat data; and columns 7 and 8 show the results using the C4-Index based on Compustat data. I measure all independent variables as of the quarter prior to the loan start date. The sample period is from 1996 to 2007 for columns 1 to 4, and 1992 to 2007 for columns 5 to 8 . All variables are defined in Appendix A. I report $t$-statistics using standard errors adjusted for within-firm clustering (OLS) or for one lag serial correlation (Fama and MacBeth) in parentheses below the coefficient estimates. Significance at the $10 \%, 5 \%$, and $1 \%$ level is indicated by $*, * *$, and ${ }^{* * *}$, respectively.

\begin{tabular}{|c|c|c|c|c|c|c|c|c|}
\hline \multirow[b]{2}{*}{ Variables } & \multicolumn{2}{|c|}{ Competition (TNIC) } & \multicolumn{2}{|c|}{ C4-Index (TNIC) } & \multicolumn{2}{|c|}{ Competition (Compustat) } & \multicolumn{2}{|c|}{ C4-Index (Compustat) } \\
\hline & $(1)$ & $(2)$ & (3) & $(4)$ & (5) & $(6)$ & $(7)$ & $(8)$ \\
\hline Competition (TNIC) & $\begin{array}{c}0.117^{* * *} \\
(4.65)\end{array}$ & $\begin{array}{l}0.030^{*} \\
(1.92)\end{array}$ & & & & & & \\
\hline C4-Index (TNIC) & & & $\begin{array}{c}-0.442^{* * *} \\
(9.02)\end{array}$ & $\begin{array}{c}-0.271^{* * *} \\
(4.57)\end{array}$ & & & & \\
\hline Competition (Compustat) & & & & & $\begin{array}{c}0.059^{* * *} \\
(2.67)\end{array}$ & $\begin{array}{l}0.042^{* *} \\
(2.26)\end{array}$ & & \\
\hline C4-Index (Compustat) & & & & & & & $\begin{array}{c}-0.218^{* * *} \\
(5.76)\end{array}$ & $\begin{array}{l}-0.102 \\
(0.87)\end{array}$ \\
\hline Log(total assets) & $\begin{array}{l}-0.278^{* * *} \\
(22.82)\end{array}$ & $\begin{array}{c}-0.275^{* * *} \\
(67.77)\end{array}$ & $\begin{array}{c}-0.282^{* * * *} \\
(22.99)\end{array}$ & $\begin{array}{l}-0.278^{* * *} \\
(36.80)\end{array}$ & $\begin{array}{c}-0.278^{* * *} \\
(28.21)\end{array}$ & $\begin{array}{c}-0.286^{* * *} \\
(81.76)\end{array}$ & $\begin{array}{c}-0.276^{* * *} \\
(27.51)\end{array}$ & $\begin{array}{c}-0.286^{* * *} \\
(42.93)\end{array}$ \\
\hline Market-to-book & $\begin{array}{c}-0.133^{* * *} \\
(7.37)\end{array}$ & $\begin{array}{l}-0.076^{* * * *} \\
(12.27)\end{array}$ & $\begin{array}{c}-0.128^{* * *} \\
(7.17)\end{array}$ & $\begin{array}{c}-0.075^{* * *} \\
(7.22)\end{array}$ & $\begin{array}{c}-0.128^{* * *} \\
(9.01)\end{array}$ & $\begin{array}{c}-0.081^{* * *} \\
(14.83)\end{array}$ & $\begin{array}{c}-0.128^{* * *} \\
(9.02)\end{array}$ & $\begin{array}{c}-0.079^{* * *} \\
(8.17)\end{array}$ \\
\hline Leverage & $\begin{array}{l}0.661^{* * *} \\
(11.47)\end{array}$ & $\begin{array}{l}0.739^{* * *} \\
(20.47)\end{array}$ & $\begin{array}{c}0.724^{* * *} \\
(11.65)\end{array}$ & $\begin{array}{l}0.681^{* * *} \\
(11.84)\end{array}$ & $\begin{array}{l}0.765^{* * *} \\
(15.72)\end{array}$ & $\begin{array}{l}0.792^{* * *} \\
(25.42)\end{array}$ & $\begin{array}{l}0.767^{* * *} \\
(15.62)\end{array}$ & $\begin{array}{c}0.801^{* * *} \\
(14.35)\end{array}$ \\
\hline Tangibility & $\begin{array}{c}-0.069^{* *} \\
(2.26)\end{array}$ & $\begin{array}{c}-0.374^{* * *} \\
(9.05)\end{array}$ & $\begin{array}{c}-0.110^{* * *} \\
(3.89)\end{array}$ & $\begin{array}{c}-0.363^{* * *} \\
(5.24)\end{array}$ & $\begin{array}{l}0.060^{* *} \\
(2.02)\end{array}$ & $\begin{array}{c}-0.338^{* * *} \\
(9.43)\end{array}$ & $\begin{array}{l}0.047 \\
(1.37)\end{array}$ & $\begin{array}{c}-0.329^{* * * *} \\
(4.89)\end{array}$ \\
\hline Cash flow volatility & $\begin{array}{l}1.872^{* *} \\
(2.44)\end{array}$ & $\begin{array}{l}0.563^{*} \\
(1.75)\end{array}$ & $\begin{array}{c}1.215^{* * *} \\
(2.65)\end{array}$ & $\begin{array}{l}0.491 \\
(1.06)\end{array}$ & $\begin{array}{c}1.091^{* * *} \\
(2.92)\end{array}$ & $\begin{array}{l}0.247 \\
(0.89)\end{array}$ & $\begin{array}{c}1.108^{* * *} \\
(2.76)\end{array}$ & $\begin{array}{l}0.184 \\
(0.44)\end{array}$ \\
\hline
\end{tabular}




\begin{tabular}{|c|c|c|c|c|c|c|c|c|}
\hline Default probability & $\begin{array}{c}0.397^{* * *} \\
(8.44)\end{array}$ & $\begin{array}{l}0.390^{* * *} \\
(16.78)\end{array}$ & $\begin{array}{c}0.342^{* * *} \\
(8.96)\end{array}$ & $\begin{array}{c}0.387^{* * *} \\
(9.57)\end{array}$ & $\begin{array}{c}0.349^{* * *} \\
(9.72)\end{array}$ & $\begin{array}{l}0.351^{* * *} \\
(17.80)\end{array}$ & $\begin{array}{c}0.336^{* * *} \\
(8.89)\end{array}$ & $\begin{array}{c}0.345^{* * *} \\
(8.46)\end{array}$ \\
\hline Profitability & $\begin{array}{c}-3.446^{* * *} \\
(11.04)\end{array}$ & $\begin{array}{c}-2.782^{* * *} \\
(14.70)\end{array}$ & $\begin{array}{c}-3.472^{* * *} \\
(11.45)\end{array}$ & $\begin{array}{c}-2.612^{* * *} \\
(9.80)\end{array}$ & $\begin{array}{c}-3.194^{* * *} \\
(12.86)\end{array}$ & $\begin{array}{c}-2.753^{* * *} \\
(17.08)\end{array}$ & $\begin{array}{c}-3.380^{* * *} \\
(12.68)\end{array}$ & $\begin{array}{c}-2.731^{* * *} \\
(10.59)\end{array}$ \\
\hline Loan size & $\begin{array}{c}-0.385^{* * *} \\
(7.36)\end{array}$ & $\begin{array}{c}-0.376^{* * *} \\
(9.97)\end{array}$ & $\begin{array}{c}-0.388^{* * *} \\
(7.22)\end{array}$ & $\begin{array}{c}-0.426^{* * *} \\
(5.39)\end{array}$ & $\begin{array}{c}-0.312^{* * *} \\
(6.40)\end{array}$ & $\begin{array}{c}-0.376^{* * *} \\
(11.41)\end{array}$ & $\begin{array}{c}-0.305^{* * *} \\
(5.77)\end{array}$ & $\begin{array}{c}-0.371^{* * *} \\
(4.87)\end{array}$ \\
\hline Log(loan maturity) & $\begin{array}{l}-0.011 \\
(0.45)\end{array}$ & $\begin{array}{c}-0.009 \\
(0.67)\end{array}$ & $\begin{array}{c}-0.026 \\
(1.17)\end{array}$ & $\begin{array}{c}-0.026 \\
(1.51)\end{array}$ & $\begin{array}{c}-0.059^{* * *} \\
(3.23)\end{array}$ & $\begin{array}{c}-0.031^{* * *} \\
(2.88)\end{array}$ & $\begin{array}{c}-0.059^{* * *} \\
(3.01)\end{array}$ & $\begin{array}{c}-0.034^{* *} \\
(2.31)\end{array}$ \\
\hline Loan type fixed effects & Yes & Yes & Yes & Yes & Yes & Yes & Yes & Yes \\
\hline Year fixed effects & No & Yes & No & Yes & No & Yes & No & Yes \\
\hline Industry fixed effects & No & Yes & No & Yes & No & Yes & No & Yes \\
\hline Estimation method & $\begin{array}{c}\text { Fama } \\
\text { MacBeth }\end{array}$ & OLS & $\begin{array}{c}\text { Fama } \\
\text { MacBeth }\end{array}$ & OLS & $\begin{array}{c}\text { Fama } \\
\text { MacBeth }\end{array}$ & OLS & $\begin{array}{c}\text { Fama } \\
\text { MacBeth }\end{array}$ & OLS \\
\hline Observations & 9,264 & 9,264 & 9,164 & 9,164 & 12,256 & 12,256 & 11,824 & 11,824 \\
\hline Average/adjusted $R^{2}$ & 0.71 & 0.67 & 0.71 & 0.69 & 0.69 & 0.66 & 0.70 & 0.66 \\
\hline
\end{tabular}


Table 5

Loan spreads and firm characteristics before and after a reduction of import tariff rates

This table presents average loan spreads and firm characteristics before and after a large reduction of import tariff rates for small and large firms. The tariff rate reduction is large if it is at least three times larger than the median tariff rate reduction in that industry. Panel A presents descriptive statistics for firms with a total asset size below the sample median, and Panel B shows the statistics for firms with a total asset size above the sample median. The sample period is from 1992 to 2005. All variables are defined in Appendix A. Significance at the 10\%, 5\%, and $1 \%$ level is indicated by *, **, and ${ }^{* * *}$, respectively.

Panel A: Small firms

\begin{tabular}{lccc}
\hline & Before & After & Difference \\
\hline Loan spread & 222.54 & 244.15 & $21.61^{* * *}$ \\
Default probability & 0.169 & 0.199 & $0.031^{* *}$ \\
Cash flow volatility & 0.024 & 0.026 & $0.002^{*}$ \\
Leverage & 0.290 & 0.289 & -0.001 \\
\hline
\end{tabular}

Panel B: Large firms

\begin{tabular}{lccc}
\hline & Before & After & Difference \\
\hline Loan spread & 88.30 & 128.12 & $39.81^{* * *}$ \\
Default probability & 0.076 & 0.133 & $0.057^{* * *}$ \\
Cash flow volatility & 0.013 & 0.013 & 0.000 \\
Leverage & 0.302 & 0.329 & $0.027^{* * *}$ \\
\hline
\end{tabular}


Table 6

Reductions of import tariff rates and the cost of debt

This table presents coefficient estimates of the effect of tariff rate reductions on loan spreads. The dependent variable is the logarithm of loan spreads. In columns 1 and 2, Post-reduction $n_{j, t}$ equals one if industry $j$ has experienced a tariff rate reduction by time $t$ that is larger than three times the median tariff rate reduction in that industry, and zero otherwise. In column 3 , Post-reduction ${ }_{j, t}$ equals one if industry $j$ has experienced a tariff rate reduction by time $t$ that is larger than $t w o$ times the median tariff rate reduction in that industry, and zero otherwise. In column 4, Post-reduction $_{j, t}$ equals one if industry $j$ has experienced a tariff rate reduction by time $t$ that is larger than three times the average tariff rate reduction in that industry, and zero otherwise. Columns 2 to 4 include loan type and three-digit SIC code industry fixed effects. The sample period is from 1992 to 2005. All variables are defined in Appendix A. I report $t$-statistics using standard errors adjusted for within-firm clustering in parentheses below the coefficient estimates. Significance at the $10 \%, 5 \%$, and $1 \%$ level is indicated by $*$, $* *$, and $* * *$, respectively.

\begin{tabular}{|c|c|c|c|c|}
\hline & $\begin{array}{c}\text { No fixed } \\
\text { effects }\end{array}$ & Baseline & $\begin{array}{l}\text { abs }(\Delta \text { Tariff }) \\
>2 \times \text { median }\end{array}$ & $\begin{array}{c}\text { abs }(\Delta \text { Tariff }) \\
>3 \times \text { mean }\end{array}$ \\
\hline & (1) & $(2)$ & (3) & (4) \\
\hline \multirow[t]{2}{*}{ Post-reduction $_{j, t}$} & $0.169^{* * *}$ & $0.221^{* * *}$ & $0.221^{* * *}$ & $0.208^{* * *}$ \\
\hline & $(5.16)$ & $(7.05)$ & $(7.75)$ & $(5.17)$ \\
\hline \multirow[t]{2}{*}{ Log(total assets) } & $-0.290^{* * *}$ & $-0.266^{* * *}$ & $-0.268^{* * *}$ & $-0.263^{* * *}$ \\
\hline & (31.159) & (30.33) & $(30.45)$ & (30.13) \\
\hline \multirow[t]{2}{*}{ Market-to-book } & $-0.106^{* * *}$ & $-0.083^{* * *}$ & $-0.081^{* * *}$ & $-0.082^{* * *}$ \\
\hline & $(6.74)$ & $(6.90)$ & $(6.79)$ & $(7.08)$ \\
\hline \multirow[t]{2}{*}{ Leverage } & $0.760^{* * *}$ & $0.639^{* * *}$ & $0.646^{* * *}$ & $0.636^{* * *}$ \\
\hline & $(8.28)$ & $(8.10)$ & $(8.17)$ & $(8.02)$ \\
\hline \multirow[t]{2}{*}{ Tangibility } & $-0.312^{* * *}$ & $-0.426^{* * *}$ & $-0.439^{* * *}$ & $-0.445^{* * *}$ \\
\hline & (3.18) & $(4.48)$ & $(4.65)$ & $(4.70)$ \\
\hline \multirow[t]{2}{*}{ Cash flow volatility } & -0.580 & -0.364 & -0.425 & -0.291 \\
\hline & $(0.73)$ & $(0.58)$ & $(0.67)$ & $(0.46)$ \\
\hline \multirow[t]{2}{*}{ Default probability } & $0.569^{* * *}$ & $0.492^{* * *}$ & $0.485^{* * *}$ & $0.494^{* * *}$ \\
\hline & $(10.51)$ & $(10.30)$ & $(10.08)$ & $(10.21)$ \\
\hline \multirow[t]{2}{*}{ Profitability } & $-3.579^{* * *}$ & $-2.896^{* * *}$ & $-2.877^{* * *}$ & $-2.986^{* * *}$ \\
\hline & $(8.75)$ & (8.19) & $(8.14)$ & (8.68) \\
\hline \multirow[t]{2}{*}{ Loan size } & $-0.604^{* * *}$ & $-0.401^{* * *}$ & $-0.403^{* * *}$ & $-0.388^{* * *}$ \\
\hline & $(8.27)$ & $(5.56)$ & $(5.61)$ & $(5.41)$ \\
\hline \multirow[t]{2}{*}{ Log(loan maturity) } & $0.139^{* * *}$ & $-0.087^{* * *}$ & $-0.086^{* * *}$ & $-0.087^{* * *}$ \\
\hline & $(7.97)$ & $(3.91)$ & $(3.87)$ & $(3.91)$ \\
\hline Loan type fixed effects & No & Yes & Yes & Yes \\
\hline Industry fixed effects & No & Yes & Yes & Yes \\
\hline Observations & 5,331 & 5,331 & 5,331 & 5,331 \\
\hline Adjusted $R^{2}$ & 0.59 & 0.68 & 0.68 & 0.68 \\
\hline
\end{tabular}




\section{Table 7}

Reductions of import tariff rates and the cost of debt: additional tests

This table presents coefficient estimates of the effect of tariff rate reductions on loan spreads. The dependent variable is the logarithm of loan spreads. Postreduction $_{j, t}$ equals one if industry $j$ has experienced a tariff rate reduction by time $t$ that is larger than three times the median tariff rate reduction in that industry, and zero otherwise. Column 1 includes additional control variables compared to the baseline specification (column 2, Table 6). I (1995<year <2001) is a dummy variable equal to one if the year is between 1995 and 2001. Column 2 shows results including firm fixed effects (FE). Column 3 includes firm and year fixed effects. Column 4 shows results for loans that are specifically refinancing loans as defined by LPC's Dealscan database. Column 5 shows results for firms that took out at least one loan before and one loan after the tariff rate reduction. Column 6 shows dynamic effects and replaces Post-reduction $n_{j, t}$ with four dummy variables: Before ${ }^{-1}$ is a dummy variable equal to one for an industry that will experience a tariff rate reduction one year prior to the event, Before ${ }^{0}$ is a dummy variable equal to one for an industry experiencing a tariff rate reduction in that year, After is a dummy variable equal to one for an industry that experienced a tariff rate reduction last year, and $A f t e r^{2+}$ is a dummy variable equal to one for an industry that experienced the tariff rate reduction at least two years ago. Column 7 shows results using import penetration as a measure of competition from foreign firms. The sample period is from 1992 to 2005 . All variables are defined in Appendix A. I report $t$-statistics using standard errors adjusted for within-firm clustering in parentheses below the coefficient estimates. Significance at the $10 \%, 5 \%$, and $1 \%$ level is indicated by $* * *$, and $* * *$, respectively.

\begin{tabular}{|c|c|c|c|c|c|c|c|}
\hline & Controls & Firm-FE & Year-FE & Refinance & Before/After & Dynamic & Import \\
\hline Variables & $(1)$ & $(2)$ & $(3)$ & (4) & (5) & (6) & $(7)$ \\
\hline Post-reduction $_{j, t}$ & $\begin{array}{c}0.154^{* * *} \\
(4.79)\end{array}$ & $\begin{array}{c}0.183^{* * *} \\
(3.51)\end{array}$ & $\begin{array}{c}0.080^{* * *} \\
(2.72)\end{array}$ & $\begin{array}{c}0.245^{* * *} \\
(5.21)\end{array}$ & $\begin{array}{c}0.231^{* * *} \\
(5.55)\end{array}$ & & \\
\hline Before ${ }^{-1}$ & & & & & & $\begin{array}{l}0.115 \\
(1.41)\end{array}$ & \\
\hline Before ${ }^{0}$ & & & & & & $\begin{array}{l}0.109 \\
(1.06)\end{array}$ & \\
\hline After ${ }^{l}$ & & & & & & $\begin{array}{l}0.220^{* *} \\
(2.29)\end{array}$ & \\
\hline After ${ }^{2+}$ & & & & & & $\begin{array}{c}0.349^{* * *} \\
(4.23)\end{array}$ & \\
\hline Import penetration & & & & & & & $\begin{array}{c}0.768^{* * *} \\
(4.72)\end{array}$ \\
\hline $\log ($ total assets $)$ & $\begin{array}{c}-0.273^{* * *} \\
(30.97)\end{array}$ & $\begin{array}{c}-0.174^{* * *} \\
(5.02)\end{array}$ & $\begin{array}{c}-0.291^{* * *} \\
(15.29)\end{array}$ & $\begin{array}{l}-0.254^{* * *} \\
(-21.13)\end{array}$ & $\begin{array}{c}-0.296^{* * *} \\
(18.78)\end{array}$ & $\begin{array}{c}-0.261^{* * *} \\
(19.84)\end{array}$ & $\begin{array}{c}-0.266^{* * *} \\
(31.41)\end{array}$ \\
\hline Market-to-book & $\begin{array}{c}-0.076^{* * *} \\
(6.18)\end{array}$ & $\begin{array}{c}-0.082^{* * *} \\
(3.45)\end{array}$ & $\begin{array}{c}-0.075^{* * *} \\
(5.99)\end{array}$ & $\begin{array}{c}-0.093^{* * *} \\
(5.73)\end{array}$ & $\begin{array}{c}-0.097^{* * *} \\
(3.05)\end{array}$ & $\begin{array}{c}-0.078^{* * *} \\
(4.86)\end{array}$ & $\begin{array}{c}-0.082^{* * *} \\
(7.12)\end{array}$ \\
\hline Leverage & $\begin{array}{c}0.661^{* * *} \\
(8.52)\end{array}$ & $\begin{array}{c}0.567^{* * *} \\
(4.34)\end{array}$ & $\begin{array}{c}0.558^{* * *} \\
(7.97)\end{array}$ & $\begin{array}{c}0.748^{* * *} \\
(7.38)\end{array}$ & $\begin{array}{c}0.823^{* * *} \\
(5.19)\end{array}$ & $\begin{array}{c}0.631^{* * *} \\
(6.89)\end{array}$ & $\begin{array}{c}0.651^{* * *} \\
(8.78)\end{array}$ \\
\hline Tangibility & $\begin{array}{c}-0.393^{* * *} \\
(4.15)\end{array}$ & $\begin{array}{c}-0.724^{* * *} \\
(3.05)\end{array}$ & $\begin{array}{c}-0.281^{* *} \\
(2.21)\end{array}$ & $\begin{array}{c}-0.434^{* * *} \\
(3.57)\end{array}$ & $\begin{array}{c}-0.687^{* * *} \\
(3.50) \\
\end{array}$ & $\begin{array}{c}-0.447^{* * *} \\
(5.03)\end{array}$ & $\begin{array}{c}-0.413^{* * *} \\
(4.51)\end{array}$ \\
\hline
\end{tabular}




\begin{tabular}{|c|c|c|c|c|c|c|c|}
\hline Cash flow volatility & $\begin{array}{l}-0.204 \\
(0.33)\end{array}$ & $\begin{array}{l}0.896 \\
(0.75)\end{array}$ & $\begin{array}{l}0.516 \\
(0.76)\end{array}$ & $\begin{array}{l}0.102 \\
(0.11)\end{array}$ & $\begin{array}{l}1.308 \\
(0.97)\end{array}$ & $\begin{array}{l}-0.512 \\
(0.79)\end{array}$ & $\begin{array}{l}-0.048 \\
(0.08)\end{array}$ \\
\hline Default probability & $\begin{array}{c}0.470^{* * *} \\
(9.53)\end{array}$ & $\begin{array}{c}0.452^{* * *} \\
(6.93)\end{array}$ & $\begin{array}{c}0.344^{* * *} \\
(9.41)\end{array}$ & $\begin{array}{c}0.460^{* * * *} \\
(7.52)\end{array}$ & $\begin{array}{c}0.529^{* * *} \\
(5.67)\end{array}$ & $\begin{array}{l}0.482^{* * *} \\
(10.06)\end{array}$ & $\begin{array}{l}0.503^{* * *} \\
(11.12)\end{array}$ \\
\hline Profitability & $\begin{array}{c}-2.815^{* * *} \\
(7.88)\end{array}$ & $\begin{array}{c}-2.743^{* * *} \\
(4.65)\end{array}$ & $\begin{array}{c}-2.114^{* * *} \\
(6.51)\end{array}$ & $\begin{array}{c}-3.316^{* * *} \\
(6.40)\end{array}$ & $\begin{array}{c}-2.638^{* * *} \\
(3.53)\end{array}$ & $\begin{array}{c}-2.887^{* * *} \\
(5.85)\end{array}$ & $\begin{array}{c}-2.900^{* * *} \\
(8.61)\end{array}$ \\
\hline Loan size & $\begin{array}{c}-0.351^{* * *} \\
(4.94)\end{array}$ & $\begin{array}{c}-0.447^{* * *} \\
(4.56)\end{array}$ & $\begin{array}{c}-0.357^{* * *} \\
(6.58)\end{array}$ & $\begin{array}{c}-0.464^{* * * *} \\
(4.61)\end{array}$ & $\begin{array}{c}-0.294^{* *} \\
(2.08)\end{array}$ & $\begin{array}{c}-0.411^{* * *} \\
(5.16)\end{array}$ & $\begin{array}{c}-0.389^{* * *} \\
(5.64)\end{array}$ \\
\hline Log(loan maturity) & $\begin{array}{c}-0.056^{* *} \\
(2.55)\end{array}$ & $\begin{array}{c}-0.071^{* * *} \\
(2.63)\end{array}$ & $\begin{array}{c}-0.040^{* *} \\
(2.35)\end{array}$ & $\begin{array}{c}-0.077^{* *} \\
(2.36)\end{array}$ & $\begin{array}{c}-0.079^{*} \\
(1.93)\end{array}$ & $\begin{array}{c}-0.078^{* * *} \\
(4.12)\end{array}$ & $\begin{array}{c}-0.079^{* * *} \\
(3.68)\end{array}$ \\
\hline Credit spread & $\begin{array}{c}0.425^{* * *} \\
(7.72)\end{array}$ & & & & & & \\
\hline Term spread & $\begin{array}{l}-0.009 \\
(0.79)\end{array}$ & & & & & & \\
\hline I $(1995<$ year <2001) & $\begin{array}{l}-0.072^{* *} \\
(2.38)\end{array}$ & & & & & & \\
\hline Real GDP growth & $\begin{array}{c}-0.011^{* *} \\
(2.20)\end{array}$ & & & & & & \\
\hline Loan type fixed effects & Yes & Yes & Yes & Yes & Yes & Yes & Yes \\
\hline Year fixed effects & No & No & Yes & No & No & No & No \\
\hline Other fixed effects & Industry & Firm & Firm & Industry & Industry & Industry & Industry \\
\hline Observations & 5,331 & 5,331 & 5,331 & 3,080 & 1,503 & 4,677 & 5,608 \\
\hline Adjusted $R^{2}$ & 0.69 & 0.81 & 0.83 & 0.69 & 0.71 & 0.68 & 0.68 \\
\hline
\end{tabular}




\section{Table 8}

Changes in import tariff rates and changes in loan spreads

This table presents coefficient estimates of the effect of changes in import tariff rates on loan spreads. The dependent variable is the change in the logarithm of loan spreads. $\Delta$ Tariff rate is the change in the import tariff rate. For each firm that took out a loan of the same type before and after a significant tariff rate reduction, I identify the last loan before and the first loan after the tariff rate reduction. Based on these observations, I compute the change in the logarithm of loan spreads, tariff rates, and firm characteristics. The sample period is from 1992 to 2005 . All variables are defined in Appendix A. I report $t$-statistics using standard errors adjusted for within-firm clustering in parentheses below the coefficient estimates. Significance at the $10 \%, 5 \%$, and $1 \%$ level is indicated by *, **, and $* * *$, respectively.

\begin{tabular}{lcc}
\hline & $(1)$ & $(2)$ \\
\hline$\Delta$ Tariff rate & $-0.141^{* *}$ & $-0.117^{* *}$ \\
& $(2.03)$ & $(1.99)$ \\
$\Delta$ Log(total assets) & $-0.213^{* * *}$ \\
& & $(2.97)$ \\
$\Delta$ Market-to-book & -0.083 \\
$\Delta$ Leverage & $(1.56)$ \\
& & 0.652 \\
$\Delta$ Tangibility & & $(1.63)$ \\
$\Delta$ Cash flow volatility & -1.848 \\
$\Delta$ Default probability & $(1.55)$ \\
& & -0.854 \\
$\Delta$ Profitability & $(1.55)$ \\
$\Delta$ Loan size & & 1.472 \\
& & $(0.49)$ \\
A Log(loan maturity) & $0.314^{* *}$ \\
Observations & $(1.99)$ \\
& & -0.280 \\
& & $(0.91)$ \\
& & $-0.212^{* *}$ \\
& & $(2.22)$ \\
& & \\
& & 211 \\
& & 0.18 \\
\hline
\end{tabular}




\section{Table 9}

Cross-sectional variation in the effect of tariff rate reductions on loan spreads

This table reports estimates of Post-reduction ${ }_{j, t}$ from a series of estimations of Eq. (2). The dependent variable is the logarithm of loan spreads. Post-reduction ${ }_{j, t}$ equals one if industry $j$ has experienced a tariff rate reduction by time $t$ that is larger than three times the median tariff rate reduction in that industry, and zero otherwise. I classify industries based on four variables: the HHI, the change in import penetration ( $\Delta$ Import penetration), the average lagged advertising and R\&D expense over sales, and the average lagged cash holdings to asset ratio of incumbent firms. For each year and for each proxy, I rank the sample industries according to their average value and assign firms from industries in the bottom and top quartiles to "low" and "high" industries, respectively. The standard errors for the differences between High and Low are computed with an SUR system that estimates the industry groups jointly. The last column Diff. high-low shows the $p$-value for the difference in the Post-reduction $_{j, t}$ coefficients between High and Low subgroups and its statistical significance. All specifications include the control variables of the baseline specification (column 2, Table 6). I measure all independent variables as of the quarter prior to the loan start date. All estimations include loan type and industry fixed effects at the three-digit SIC code industry level. The sample period is from 1992 to 2005. All variables are defined in Appendix A. $t$-Statistics are in parentheses below the coefficient estimates and the number of observations in each group is in italics. Significance at the $10 \%, 5 \%$, and $1 \%$ level is indicated by $*$, **, and ${ }^{* * *}$, respectively.

\begin{tabular}{|c|c|c|c|}
\hline & Low & High & Diff. high - low \\
\hline \multicolumn{4}{|l|}{ Industry concentration and imports } \\
\hline$H H I$ & $\begin{array}{c}0.126^{* * *} \\
(2.93) \\
907\end{array}$ & $\begin{array}{c}0.416^{* * *} \\
(9.34) \\
797\end{array}$ & $0.00^{* * *}$ \\
\hline$\Delta$ Import penetration & $\begin{array}{c}0.099^{* *} \\
(1.97) \\
887\end{array}$ & $\begin{array}{c}0.253^{* * *} \\
(5.53) \\
754\end{array}$ & $0.02^{* *}$ \\
\hline \multicolumn{4}{|l|}{ Barriers to entry } \\
\hline Advertising and $R \& D$ & $\begin{array}{c}0.316^{* * *} \\
(7.19) \\
878\end{array}$ & $\begin{array}{c}0.203^{* * *} \\
(4.35) \\
693\end{array}$ & $0.08^{*}$ \\
\hline Cash holdings of incumbent firms & $\begin{array}{c}0.270^{* * *} \\
(6.00) \\
888\end{array}$ & $\begin{array}{c}0.148^{* * *} \\
(2.98) \\
683\end{array}$ & $0.07^{*}$ \\
\hline
\end{tabular}




\section{Table 10}

Cross-sectional variation in the effect of competition on loan spreads: financial strength and strategic interactions

This table reports estimates of Competition from a series of estimations of Eq. (1). The dependent variable is the logarithm of loan spreads. Competition is a dummy variable equal to one if the HHI at the three-digit SIC code industry level is in the lowest quartile of the yearly sample distribution, and zero otherwise. For Rivals' size, I classify small firms (below sample median) into two groups based on the median: firms facing small (Low) and large rivals (High). For Rivals credit rating I classify firms without a credit rating into two groups based on the average rivals' credit ratings: firms facing low (Low) and high (High) rated firms. For the C4-Index and the Similarity of operations proxy, each year and for each proxy, I rank the sample industries according to their average value and assign firms from industries in the bottom and top quartiles to "low" and "high" industries, respectively. The columns Diff. high-low show the $p$-value for the difference in the Competition coefficients between High and Low subgroups and its statistical significance. All the estimations contain the control variables of the baseline specification (column 3, Table 3) and include loan type dummies. The OLS estimations include year and industry fixed effects at the three-digit SIC code industry level. The sample period is from 1992 to 2007. All variables are defined in Appendix A. $t$-Statistics are in parentheses below the coefficient estimates and the number of observations in each group is in italics. Significance at the $10 \%, 5 \%$, and $1 \%$ level is indicated by *, **, and ***, respectively.

\begin{tabular}{|c|c|c|c|c|c|c|}
\hline & \multicolumn{3}{|c|}{$O L S$} & \multicolumn{3}{|c|}{ Fama and MacBeth } \\
\hline & Low & High & Diff. high - low & Low & High & Diff. high - low \\
\hline \multicolumn{7}{|l|}{ Differences in financial strength } \\
\hline \multirow[t]{3}{*}{ Rivals' size for small firms } & -0.007 & $0.151^{* * *}$ & $0.00^{* * *}$ & -0.007 & $0.209^{* * *}$ & $0.00^{* * *}$ \\
\hline & $(0.19)$ & $(3.42)$ & & $(0.21)$ & (3.83) & \\
\hline & 2,971 & 2,968 & & 2,971 & 2,968 & \\
\hline \multirow[t]{3}{*}{ Rivals' rating for unrated firms } & $0.061^{*}$ & $0.087^{*}$ & 0.67 & 0.022 & $0.142^{* *}$ & $0.04^{* *}$ \\
\hline & $(1.72)$ & $(1.75)$ & & $(0.97)$ & $(2.16)$ & \\
\hline & 4,512 & 2,884 & & 4,512 & 2,884 & \\
\hline \multicolumn{7}{|l|}{ Strategic interactions } \\
\hline \multirow[t]{3}{*}{ Industry concentration (C4-Index) } & $0.089^{* *}$ & $0.317^{* * *}$ & $0.00^{* * *}$ & -0.001 & $0.140^{* *}$ & $0.03^{* *}$ \\
\hline & $(1.96)$ & $(4.21)$ & & $(0.04)$ & $(2.46)$ & \\
\hline & 3,001 & 2,938 & & 3,001 & 2,938 & \\
\hline \multirow[t]{3}{*}{ Similarity of operations } & $0.166^{* * *}$ & $0.139^{* * *}$ & 0.73 & 0.069 & $0.155^{* * *}$ & 0.22 \\
\hline & $(2.97)$ & $(2.56)$ & & $(1.45)$ & $(2.98)$ & \\
\hline & 2,703 & 2,753 & & 2,703 & 2,753 & \\
\hline
\end{tabular}




\section{Table 11}

Cross-sectional variation in the effect of competition on loan spreads: asset specificity and illiquidity

This table reports estimates of Competition from a series of estimations of Eq. (1). The dependent variable is the logarithm of loan spreads. Competition is a dummy variable equal to one if the HHI at the three-digit SIC code industry level is in the lowest quartile of the yearly sample distribution, and zero otherwise. I classify industries based on four variables: the proportion of machinery and equipment to total assets (Asset specificity), the inverse of the quick ratio (Asset illiquidity), the average leverage net of cash of rival firms (Net leverage of rivals), and the number of competitors in the same industry with a credit rating (Number of potential buyers). For each year and for each proxy, I rank the sample industries according to their average value and assign firms from industries in the bottom and top quartiles to "low" and "high" industries, respectively. The columns Diff. high-low show the $p$-value for the difference in the Competition coefficients between High and Low subgroups and its statistical significance. All the estimations contain the control variables of the baseline specification (column 3, Table 3) and include loan type dummies. The OLS estimations include year and industry fixed effects at the three-digit SIC code industry level. The sample period is from 1992 to 2007. All variables are defined in Appendix A. $t$-Statistics are in parentheses below the coefficient estimates and the number of observations in each group is in italics. Significance at the $10 \%, 5 \%$, and $1 \%$ level is indicated by *, **, and ***, respectively.

\begin{tabular}{|c|c|c|c|c|c|c|}
\hline & \multicolumn{3}{|c|}{$O L S$} & \multicolumn{3}{|c|}{ Fama and MacBeth } \\
\hline & Low & High & Diff. high - low & Low & High & Diff. high - low \\
\hline Asset specificity & $\begin{array}{c}0.106^{* *} \\
(2.11) \\
2,901\end{array}$ & $\begin{array}{c}0.289^{* * *} \\
(4.04) \\
2,712\end{array}$ & $0.03^{* *}$ & $\begin{array}{c}-0.015 \\
(0.45) \\
2,901\end{array}$ & $\begin{array}{c}0.0584 \\
(0.72) \\
2,712\end{array}$ & 0.40 \\
\hline Asset illiquidity & $\begin{array}{c}0.096^{* *} \\
(2.28) \\
3,155\end{array}$ & $\begin{array}{c}0.243^{* * *} \\
(2.91) \\
2,957\end{array}$ & 0.11 & $\begin{array}{c}-0.004 \\
(0.13) \\
3,155\end{array}$ & $\begin{array}{c}0.239^{* * *} \\
(3.94) \\
2,957\end{array}$ & $0.00^{* * *}$ \\
\hline Net leverage of rivals & $\begin{array}{c}0.103^{* * *} \\
(2.82) \\
3,174\end{array}$ & $\begin{array}{c}0.206^{* * *} \\
(4.11) \\
2,816\end{array}$ & $0.09^{*}$ & $\begin{array}{l}0.001 \\
(0.04) \\
3,174\end{array}$ & $\begin{array}{c}0.138^{* * *} \\
(2.93) \\
2,816\end{array}$ & $0.01^{* *}$ \\
\hline Number of potential buyers & $\begin{array}{c}0.189^{* * *} \\
(3.06) \\
3,182\end{array}$ & $\begin{array}{c}0.109^{* *} \\
(2.66) \\
2,960\end{array}$ & 0.28 & $\begin{array}{c}0.116^{*} \\
(1.80) \\
3,182\end{array}$ & $\begin{array}{r}-0.011 \\
(0.18) \\
2,960\end{array}$ & $0.10^{*}$ \\
\hline
\end{tabular}

